\title{
Milk and meat consumption and production in Chile, c. 1930-2017: A history of a successful nutrition transition
}

\author{
Manuel llorca-Jaña, Ricardo Nazer, Daniel Morales-Campos \\ \& JUAN NAVARrETE-MONTALVO
}

KEYWORDS: meat, dairy products, Chile, nutrition transition.

\author{
JEL CODES: I18, N53, N56, Q17.
}

his article shows how Chile experienced a profound nutrition transition
within a short period of time. Before the early 1990s, the diet of most Chileans
was poor in animal proteins and calcium. Today, Chileans enjoy a diet characterized by high consumption of meat and dairy products. The rapid rise in consumption of these products can be attributed to various factors: Chile belatedly joining the international agribusiness revolution; government support from the 1930s to the 1960s; increasing GDP per capita; macro-economic stability; changes in consumption habits; trade liberalization; and the fall in food prices, as both meat and milk had high income elasticity. These revolutions in both production and consumption have greatly improved the nutrition of the Chilean population and partly explain the improvement in Chile's biological well-being. 


\section{Consumo y producción chilena de carnes y leche, c. 1930-2017: Una historia de transición nutricional exitosa}

\section{PALABRAS CLAVE: carnes, productos lácteos, Chile, transición nu- tricional.}

\section{CÓDIGOS JEL: I18, N53, N56, Q17.}

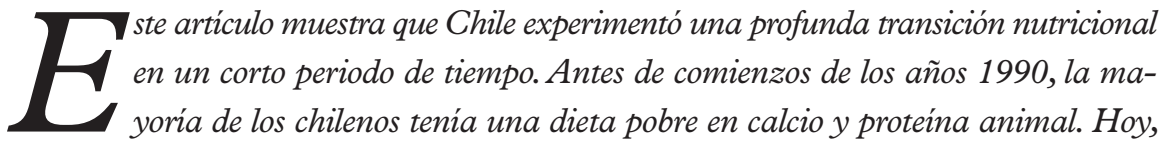
sin embargo, los chilenos disfrutan de una dieta caracterizada por un alto consumo de carne y productos lácteos. El aumento súbito en el consumo de carnes y productos lácteos está principalmente asociado a la adopción en Chile de la revolución internacional en agronegocios; al apoyo gubernamental entre las décadas de 1930 y 1960; a un aumento del PIB per cápita; la estabilidad macroeconómica; los cambios en hábitos de consumo; la liberalización comercial; y a la caída de precios de los alimentos, que tienen una alta elasticidad de demanda. Estas revoluciones en producción y consumo han mejorado de gran manera la nutrición de la población chilena, lo que explica parte de las mejoras en bienestar biológico del país.

Received: 2019-08-18 - Revised: 2020-01-08 - Accepted: 2020-02-04

Manuel Llorca-Jaña [orcid.org/0000-0002-3937-6035] is Full Professor at the Escuela de Administración Pública, Universidad de Valparaíso. Address: Las Heras 6,Valparaíso (Chile). E-mail: manuel.llorca@uv.cl

Ricardo Nazer [orcid.org/0000-0003-3393-0346] is an Associate Researcher at Universidad deValparaíso. Address: Las Heras 6, Valparaiso (Chile).E-mail:jrnazer@gmail.com

Daniel Morales [orcid.org/0000-0002-5581-8542] is an Associate Researcher at Universidad deValparaíso. Address: Las Heras 6,Valparaíso (Chile).E-mail: daniel.moralesc@usach.cl

Juan Navarrete-Montalvo [orcid.org/0000-0003-3962-5676] is an Associate Researcher at Universidad deValparaíso. Address: Las Heras 6, Valparaíso (Chile).E-mail:juan.navarrete@uv.cl 


\section{INTRODUCTION}

This article deals with the evolution of Chile's dairy product and meat consumption between c. 1930 and 2018, analyzing the interaction between supply and demand of two unusual sectors within Chilean agriculture. In contrast with most sectors of the economy, most of the dairy and meat output was destined for home consumption. Before 1930, sound continuous statistical information was not available, but the situation in 1930 appears to have been similar to that of the 1900s-1920s. Our new data provides confirmation that, by international standards, between the 1930s and the early 1990s the diet of most Chileans was lacking in animal proteins and calcium compared to that of the developed world, and that this was the case at least since the mid-nineteenth century.

Previous studies have shown that beginning in the mid-nineteenth century there was a deterioration in the biological welfare of the Chilean population which continued until the early twentieth century and that this was due, in part, to a poor diet, even poorer than during the colonial period (Llorca-Jaña et al., 2019; Llorca-Jaña et al., 2018b). A report written by two French specialists in nutrition for the League of Nations in the mid1930s concluded that, at the time of writing, half of the Chilean population did not consume the minimum recommended intake of calories and proteins (Dragoni \& Burnet, 1938) and were highly reliant on wheat-based products such as bread (Santa María, 1935). The agricultural sector was unable to provide enough food for the population, and this situation was widely known as the agrarian problem of Chile (Mamalakis, 1976; Gallardo, 2017). The situation remained largely unchanged until the mid-1980s.

Currently, Chileans enjoy a diet characterized by a high consumption of meat and dairy products: the country experienced a profound nutrition transition within a short period of time, although this process happened late if compared to more developed countries, and even some middle-income countries comparable to contemporary Chile. In short, this nutrition transition meant that a diet based on carbohydrates and fiber gave way to a more varied diet incorporating a higher proportion of animal proteins ${ }^{1}$. During our period of study, per capita meat consumption stagnated between the 1930s and 1980s but increased dramatically thereafter. Per capita milk consumption increased substantially during the 1990s-2010s, having also increased during the 1930s-1960s (but stagnated or declined during the 1970s-1980s, at times when inequality was on the increase in the country; Rodríguez Weber, 2017). The sudden rise in consumption of these two sets of products during the last three decades is mainly associated with the following factors: Chile's belated

1. Dairy products and meat are two of the key products at the root of the nutrition transition in the Western world (CollanTES, 2014). 
participation in the international agribusiness revolution that had a heavy impact on meat and milk production ${ }^{2}$, the increase in GDP per capita and real wages, macro-economic stability, trade liberalization, increasing participation of private firms, government campaigns to promote consumption of meat and milk, and the falling prices of food, with both set of products retaining a high income elasticity (Clar, 2008). It is important to stress that the Chilean experience has been heavily influenced by international historical developments and must be analyzed with regard to the concept of food regimes whereby agriculture and food are interpreted in relation to the international development of capitalism (Magnan, 2012; Friedmann \& McMichael, 1989).

This sharp increase in the per capita consumption of meat and dairy products in Chile beginning in the 1990s is important for several reasons. First, milk and meat were increasingly produced worldwide in agro-industrial establishments, and the rise of the agroindustrial diet was the culmination of a nutritional transition within western countries, with wide implications for biological welfare (Popkin, 1993; Grigg, 1995; Collantes, 2019b; Nierenberg, 2005). The precise timing of these phenomena has not been documented for either Chile or most other Latin American countries (except Brazil; e. g. Monteiro et al., 1995; Conde \& Monteiro, 2014). This nutritional transition was clearly completed far earlier in the developed world than it was in Chile and was characterized by the increasing consumption of animal-based foods, in preference to cereals and other products less rich in proteins (Clar, 2008).

Second, both foodstuffs are considered to be amongst the most important nutrients determining the biological welfare of a population (Steckel, 1995; Baten \& Blum, 2014). The average height of a population, for instance, is thought to be highly dependent on milk and meat intake between conception and 18-20 years of age. The stature of male adults increased significantly in Chile during the 1990s-2000s (Llorca-Jaña, Araya \& Navarrete, 2018a). The increase of meat and dairy consumption in Chile greatly contributed to these gains in human stature. The increasing international consumption of these foodstuffs, especially milk, is also credited with reducing infant mortality (Pujol, Nicolau \& Hernández Adell, 2007).

This article explains what made possible the dramatic increase in both meat and milk per capita consumption in the country. The article is focused on the evolution of GDP per capita and real wages in Chile (key determinants of local demand), on the main

2. For example, between 1950 and 2005 global meat production increased more than five-fold, with pork, followed by chicken, being the most popular product (NIERENBERG, 2005). See also ClaR (2010). 
organizational and technological innovations introduced by the related industries to cope with increasing demand, on the role of foreign trade, on changes in consumption habits, and on government policies that fostered the agricultural sector and promoted consumption.

For example, it is clear that during the 1930s-1960s local supply received government support to introduce technological innovations while there were extensive price controls. In contrast, beginning in the mid-1970s there was deregulation, characterized by price liberalization, trade liberalization and the increasing participation of the private sector, combined with increasing average household income. This development is similar to the international transition of the food system from extensive state intervention (c. 1930s1970s) to an era of greater coordination through markets during the so-called neoliberal globalization (Friedmann \& McMichael, 1989). The phenomenon has been labelled a transition from "organized capitalism" to "disorganized capitalism", with less government and more market, involving a shift from a seller's to a buyer's market (Shuurman, 2013) ${ }^{3}$. This article contributes to the literature on both economic history ${ }^{4}$ and the biological welfare of a peripheral country: Chile.

\section{SOURCES AND METHODOLOGY}

We have constructed a new database on the apparent consumption of both meat and milk (defined as national production plus imports minus exports) and created new series on annual national production, imports and exports for meat and dairy products. To estimate dairy consumption, we converted all the information on production, imports and exports to liters of milk. The original data on production is in liters, although diverse dairy products were produced, sometimes in industrial plants. We collected data on quantities traded abroad of liquid milk, powdered milk, cheese, butter, condensed and evaporated canned milk, with all units converted to the equivalent liters of milk ${ }^{5}$.

3. This conventional wisdom has been recently challenged by COLLANTES (2019a), who has convincingly argued that it is unclear that there was such a sharp discontinuity. According to Collantes, although it is true that there have been elements of state-coordinated capitalism before the 1980s in the international food economy, as well as elements of liberalization thereafter, it is also the case that the structure of economic coordination involved some combination of market and nonmarket mechanisms during both periods.

4. The livestock sector in particular has received little attention within the agrarian history of the country (GALLARDO, 2017).

5. The ratios to convert quantities of processed dairy products into liters of milk, which applies only to foreign trade data (since national production is already in liters), were those used by ODEPA (the Chilean Government's Office for Policy and Agrarian Studies): $1 \mathrm{~kg}$ of condensed -or evaporated- 
We collected data on the main meats consumed in Chile, with the data available as ready-to-cook kilograms or tons. We also collected data on the annual national production of meat, exports and imports for the meats most frequently consumed in the country, to calculate the apparent consumption of bovine, ovine, pork, poultry and equine meat, and converted all data to kilograms of meat per person, adding different meats together, which is a standard practice ${ }^{6}$. The data on population comes from Díaz Bahamonde, Lüders and Wagner (2016), except for the last few years, when we used the latest census information. Data from GDP per capita was gathered from the same source (Díaz Bahamonde, Lüders \& Wagner, 2016), while data on real wages came from other secondary sources. We also collected some data from the National Office of Statistics, in particular the weights of meat and dairy products within the consumer price index from 1928 to 2008 , and the average monthly expenditure of Chilean households on meat and dairy products, according to the Surveys of Family Budget from 1978 to 2017, aiming to triangulate our evidence as in Collantes (2016), in a similar study for the dairy market in Spain.

Finally, we compared our data to that of FAOSTAT, widely used by other colleagues dealing with other countries and these products. However, FAOSTAT started in 1961 while our data began in 1930, and FAO data ended in 2013, five years before our data ended. Consequently, we have added thirty-five years to the period covered by FAOSTAT. Second, and more important, FAOSTAT data for the consumption of dairy products was based on indirect estimates rather than direct calculations as used here. Collantes (2016) has already shown that for the dairy sector, FAOSTAT's data on national consumption differed substantially from data based on national sources. For these reasons we used national statistics, which are better quality than those provided by FAO (Collantes, 2016), although we recognize that FAOSTAT does capture general long-term trends and is useful for comparison across countries. We compared our data with that of FAOSTAT and the results were roughly the same for the period 1961-2013 (data available upon request), confirming that FAOSTAT provides good quality data on meat.

milk $=2.7$ liters of milk; $1 \mathrm{~kg}$ of whole milk powder $=7.89$ liters of milk; $1 \mathrm{~kg}$ of skimmed milk powder $=11.49$ liters of milk; $1 \mathrm{~kg}$ of semi-skimmed milk powder $=9.69$ liters of milk; $1 \mathrm{~kg}$ of butter $=$ 28 liters of milk; $1 \mathrm{~kg}$ of cheese $=6.6$ liters of milk.

6. Unfortunately, there is no continuous series on fish and meat consumption for Chile for the whole period we are working with. Per capita consumption appears to have been remarkably stable between the 1930s and 1990s. In the 1930s the combined consumption of fish and seafood was 6.8 $\mathrm{kg}$ per capita per annum (low for a country with thousands of kilometres of coast), while in the 1980s and $1990 \mathrm{~s}$ it was $5.6 \mathrm{~kg}$ and $6.1 \mathrm{~kg}$, respectively. Only during the last two decades have Chilean people started to consume over $10 \mathrm{~kg}$ of fish-seafood per person per annum, on average, reaching around $13 \mathrm{~kg}$ during the $2010 \mathrm{~s}$, thanks to the adoption of aquaculture techniques (i.e. fish raised on farms).

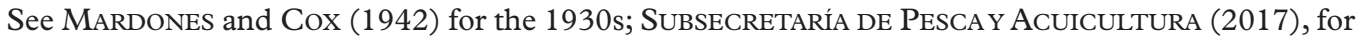
the 1980 s to the present. 


\section{THE DAIRY SECTOR: PRODUCTION, FOREIGN TRADE AND CONSUMPTION}

Figure 1 depicts Chile's annual average per capita consumption of dairy products per decade. There was a steady growth from sixty-seven liters per person per year in the 1930s to 118 liters per capita in the $1960 \mathrm{~s}^{7}$; consumption nearly doubled in three decades, although the starting point was $l^{8}{ }^{8}$. This was a period when milk had been increasingly widely acknowledged internationally as a key foodstuff for growth and nutrition, which could not be substituted, so world consumption increased significantly (Valenze, 2011). GDP per capita in Chile also increased steadily during the 1930s-1960s, and was $71 \%$ higher in 1969 than it was in 1930 (Figure 2). Real wages increased for much of this period (except for part of the 1950s; Figure 6, below), so the increasing dairy consumption is unsurprising considering that the 1930s-1960s were characterised by the active involvement of the Chilean State in the economy, including the implementation of programs to promote milk production and consumption, as discussed below (Millar \& Fernández Abara, 2008).

During the 1970s-1980s, though, there was decline or stagnation, when average consumption per person decreased to around 105 liters per annum. Our data is consistent with a recent study (Moreno, 2017) based on the Surveys of Family Budget conducted by the National Institute of Statistics approximately every ten years, which concluded that the real expenditure on dairy products decreased by $13 \%$ between 1957 and 1988 . This decline reflects the fact that the 1970s and most of the 1980s were harsh years for the Chilean economy, characterized by macroeconomic instability (e.g. inflation) following the military coup in 1973 and the financial and economic crisis of 1982, the worst part of the second half of the century for Chile. The per capita GDP level of 1971 was reached again only in 1980-81, then plummeted, and only superseded the 1971 level in 1988 (Figure 2).

Furthermore, the national dairy industry was particularly badly hit by the liberalization of the economy following the 1973 coup: Pinochet's economic advisors recommended the price liberalization of all products -including milk-, as well as a gradual import duty reduction on most products -including powdered milk, which impacted

7. For previous periods, in the late 1910 s, milk consumption was estimated at around 48 liters per person per annum (GALlaRdo, 2017).

8. This fact was acknowledged by contemporaries (YÁÑEZ ANDRADE, 2019). However, although the consumption of dairy products was low, as average family incomes were also low, the share of dairy products within the first Consumer Price Index basket of Chile was a respectable $4.7 \%$ (see Appendix, Table 3). 
FIGURE 1

Chilean per capita consumption of dairy products

(equivalent to liters per person, yearly averages per decade)

180

160

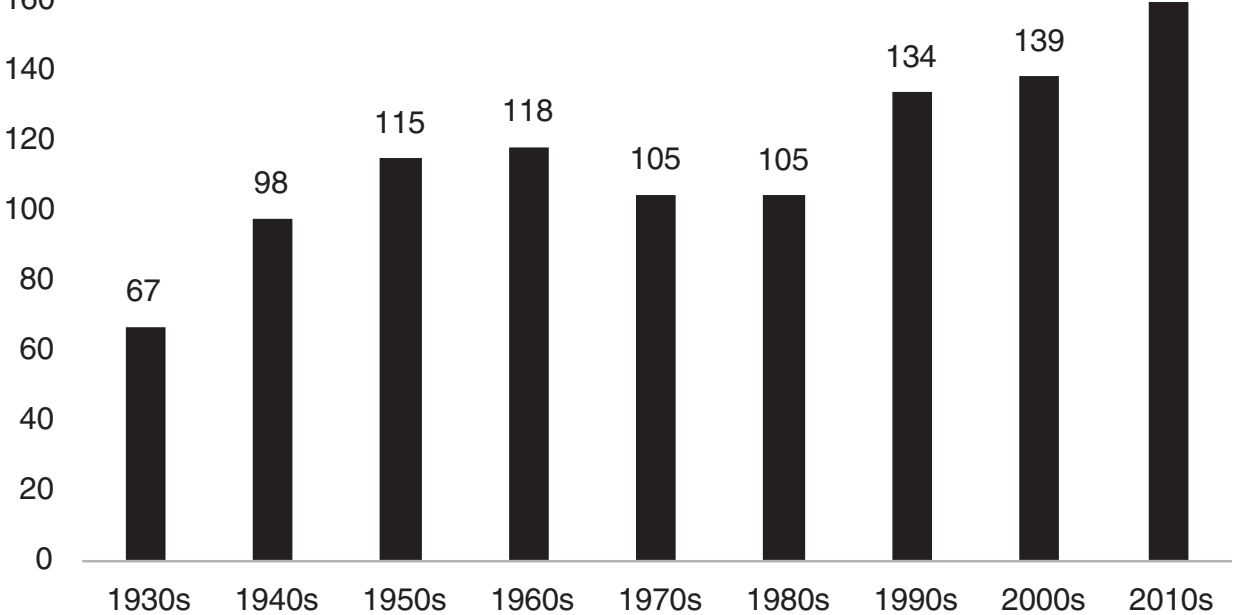

Sources: ODEPA (1983-1990); ODEPA (1991-2019); ODEPA (1990-2017); Banco Central de Chile (19772019); Oficina Central de Estadística de Chile (1930-1982); Cámara de Comercio de Santiago (1967-1982); CEPAL (1971-1989).

FIGURE 2

\section{Chilean real GDP per capita (pesos of 2003)}

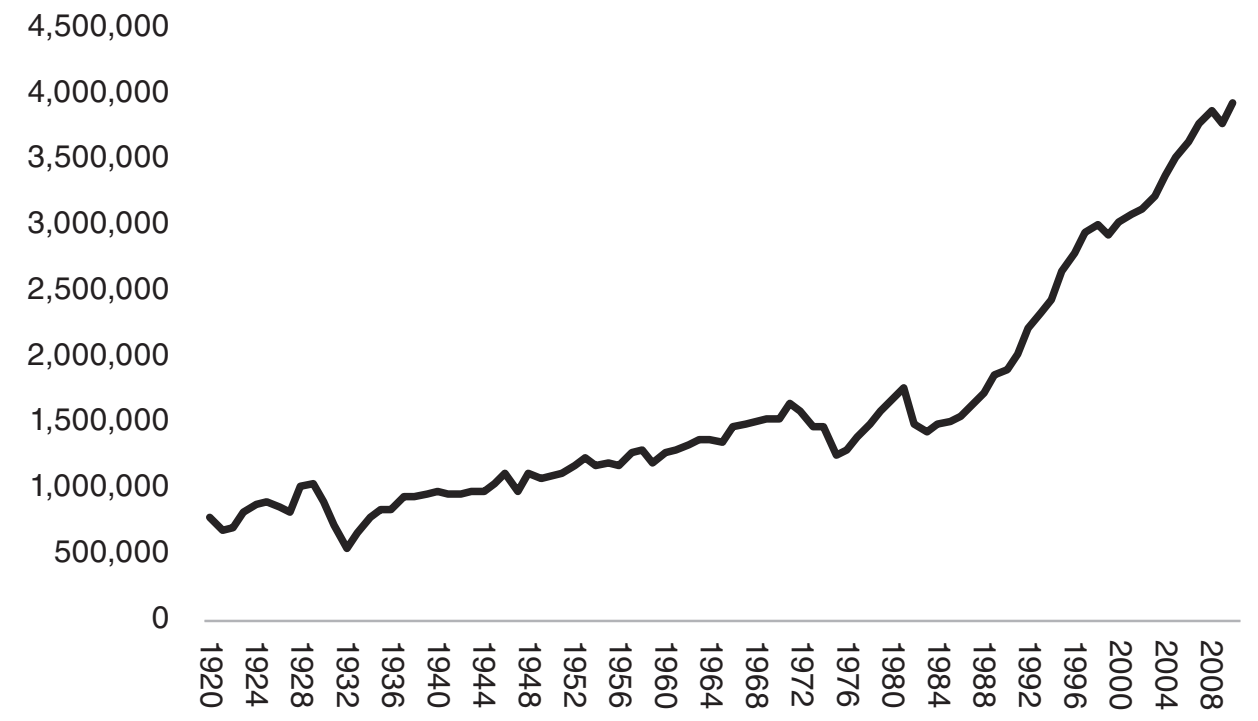

Source: Díaz Bahamonde, Lüders and Wagner (2016). 
negatively on the national milk industry (Almonacid, 2016). This process of deregulation was part of the international progress made by the neoliberal agenda in the world political economy (Collantes, 2019a). Although, from the consumers' point of view, imported powdered milk could now enter the market at lower prices -thus benefiting consumers, it did not compensate for the lowering of national production and GDP per capita due to the economic crisis of the period: consumption was harshly hit. Credit, formerly available from the Government (through $\mathrm{CORFO}^{9}$ and Banco Estado) at low rates to milk producers, was now only available from the private banking sector at higher interest rates, thus deterring new investments needed to modernize the industry, a process which had started in the 1930s, and which had been maintained until the previous decade (Aravena, 2014).

However, from the mid-1980s onwards milk consumption increased continuously, and the equivalent of 160 liters per person per annum was consumed in the 2010s, which is roughly the amount recommended by the World Health Organization (Fedeleche, 2013). For the first time in their history, Chileans were consuming a suitable quantity of dairy products. The sustained economic growth of the country from the late-1980s, including an increase in real wages, combined with decreasing milk prices (in particular during the 1990s; see Figure 3), helped to foster this process, as did the high income elasticity of the demand for dairy products (Pujol, Nicolau \& Hernández Adell, 2007). The dairy sector was perceived as amongst those with the highest potential growth of demand (Ríos \& Coq, 2012). Between 1930 and 2017 the national per capita consumption of milk (in liters) increased nearly three-fold, a remarkable achievement for a middle-income country. The increase in the last two decades is also attributable to effective publicity campaigns by the National Milk Producers Association (Fedeleche), framed within the I drink milk campaign strategy (Ríos \& Coq, 2012). According to data provided by $\mathrm{FAO}^{10}$, per capita consumption of dairy products in Chile is above that of most countries in Latin America, except for Uruguay, Costa Rica, Argentina and Brazil. However, it is still lower than in the USA and the UK.

We have contrasted our data on per capita consumption in liters with data on expenditure in Chilean pesos, according to the Surveys of Family Budget (EPF in Spanish), for Greater Santiago, for a longer and later period than that covered by Moreno (2017). These

9. CORFO, or Corporación de Fomento de la Producción, was created in 1939. It was a national development bank which became heavily involved in infrastructural and industrial investments, as well as economic planning in many sectors of the economy, including the agricultural sector (MiLLAR \& FERNÁNDEZ ABARA, 2008).

10. http://www.fao.org/faostat/es/\#data/FBS [Accesed: 20 ${ }^{\text {th }}$ March 2018]. 


\section{FIGURE 3}

Real milk prices per liter (pesos of March 2019), paid to producers, 1979-2006 300

250

200

150

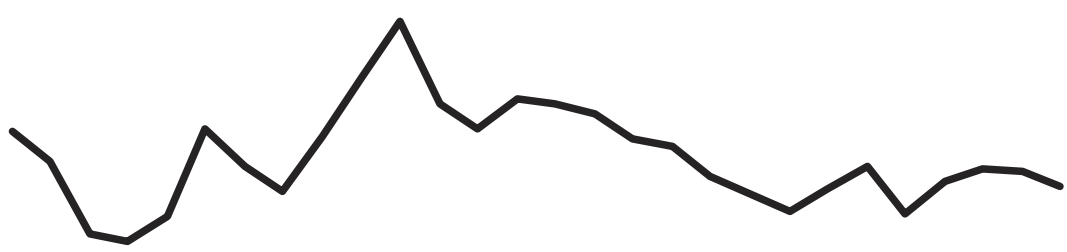

100

50

0

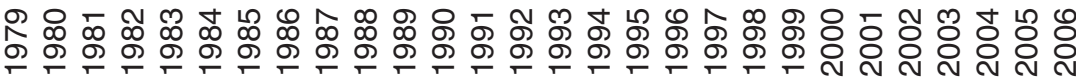
Source: ODEPA (1983-1990); ODEPA (1991-2019).

FIGURE 4

Real monthly per capita expenditure on dairy products (pesos of June 2017), according to the Surveys of Family Budget for Greater Santiago, quantiles 1 (Q1) and 2 (Q2)

6,000

5,000

4,000

3,000

2,000

1,000

0

$\begin{array}{llllll}1978 & 1988 & 1997 & 2007 & 2012 & 2017\end{array}$

Dairy products Q1 $\longrightarrow$ Dairy products Q2

Source: own elaboration from National Institute of National Statistics, all Surveys of Family Budget from 1978, available at https://www.ine.cl/estadisticas/ingresos-y-gastos/epf [Accesed: 30 $0^{\text {th }}$ March 2018]. 
surveys were conducted roughly every ten years, and from the late 2000s every five years. Our new data shows that for the first and second quintiles (the poorest strata of society) the real per capita expenditure in dairy products increased five-fold and three-fold respectively between 1988 and 2017; this was a remarkable increase (Figure 4), thus further confirming the results shown in Figure 1.

The driving force behind this dramatic increase in per capita consumption of milk products during the last three decades has been a dynamic national dairy industry, rather than foreign trade (i.e. imports): production increased from around 0.9 million liters per annum during the 1970 s to over 2.25 million liters during the most recent decade (Figure 5). Net imports (i.e. imports minus exports) have played a role, but they were more important during the 1950s-1990s than thereafter, since the country started to export greater quantities of dairy products in the mid-1990s (in part due to the signature of extensive bilateral trade agreements; Llorca-Jaña, 2015), balancing out many of the imported dairy products.

\section{FIGURE 5}

\section{National production (million liters) and dairy product imports and exports (converted to million liters), annual averages per decade 3,000}

$$
2,500
$$$$
2,000
$$$$
1,500
$$$$
1,000
$$

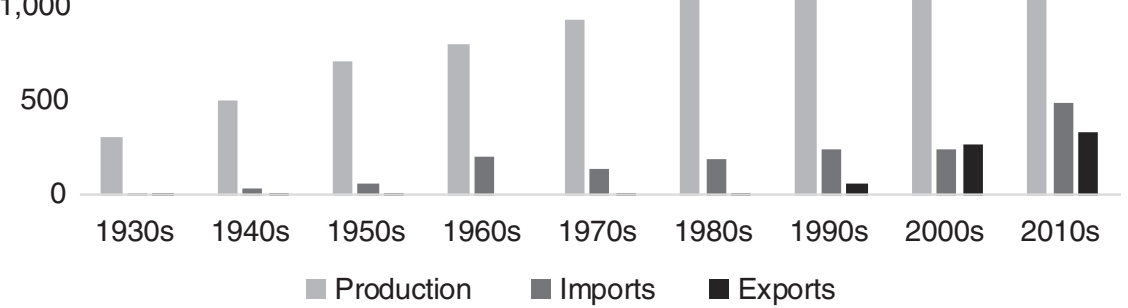

Sources: ODEPA (1983-1990); ODEPA (1991-2019); ODEPA (1990-2017); Banco Central de Chile (19772019); Oficina Central de Estadística de Chile (1930-1982); Cámara de Comercio de Santiago (1967-1982); CEPAL (1971-1989).

How to account for such a substantial increase in national milk production? Although the most dramatic increase came during the 1990s, the basis for this growth can be traced 
back to the period between the 1930s and the early 1960s and was due to both active state intervention and successful private entrepreneurship. The 1930s saw the creation of the Milk Industry Council (Consejo de la Industria Lechera), entrusted by the Government with the promotion of production, distribution and consumption of milk and ensuring low prices (Mardones \& Cox, 1942; Almonacid, 2011). Amongst the specific initiatives undertaken by this Council, cheap credit was made available to milk producers to invest in new technologies and facilities. From 1938 some joint private-public initiatives also took place. These included the creation of the Sociedad Nacional Lechera (National Milk Society), in which the State joined forces with the Swiss multinational Nestlé to ensure enough supplies for the increasing demands of a milk program run by the Caja del Seguro Obrero (a public institution created in 1924, entrusted with social security). The Caja, apart from providing pensions, work, accident and death insurance, had also created the Mother and Child Service and a school breakfast programme to provide milk for children from the lowest strata of society (Aguilera \& Zúñiga, 2006; Moreno, 2017; Mardones \& Cox, 1942). Milk cooperatives were promoted (Almonacid, 2011): in 1942 the Cooperativa Agrícola y Lechera de Osorno (CALO) was launched, then, in 1949, the Cooperativa Agrícola y Lechera de la Unión (COLUN), followed by Loncoleche in 1961 (Moreno, 2017), which took production to a higher level.

In addition, new bovine breeds were introduced into the country by private entrepreneurs ${ }^{11}$ with governmental support, which were bred specifically for milk production ${ }^{12}$. These livestock improvement initiatives were part of a global trend. Beginning in the early twentieth century there were important international advances in the genetic mix of Holstein and Jersey cows, greatly improving milk production per day per cow. This development coincided with a better process of ensuring high quality semen and artificial insemination, which had been pioneered in the 1930s, improving the quality of the Holstein-Friesian cows (Valenze, 2011). Thanks to the new investments made in infrastructure, as well as these other initiatives, by the late 1950s the milk industry in Chile was acknowledged as only one of two industries (the other was sugar refining) employing advanced technology in the production process (Moreno, 2017).

11. Gallardo's PhD thesis (2017) highlights the important role played by Osorno's livestock farmers by introducing new bovine races from Germany, the USA, Great Britain and Switzerland.

12. Previously, according to a government report produced in 1942, most cows in Chile were destined for both meat and milk production. In turn, those producers selling milk in the market had on average just 22 cows each, which is evidence of artisan production. These cows produced as little as 2.3 liters per day, on average (MARDONES \& Cox, 1942). By the mid-1960s the yield had increased to 4.9 liters per day (MINISTERIO DE AGRICULTURA, 1970). 
As the industry developed, the most important set of policies were those applied under Jorge Alessandri's government (1959-64), when new initiatives to promote milk production in Chile were implemented. They were framed within the National Program of Economic Development for 1961-70, which included sectorial plans, including one designed for the livestock sector (CORFO, 1961). This plan was to be implemented through $\mathrm{CORFO}$ and in particular through its Agricultural Management Office, which had been created in 1959. The livestock plan included specific credit schemes to fund the construction of additional modern milk plants (including up-to-date milking facilities), new initiatives for the further cultivation of cows bred for milk production, better meadows (cultivated with better seeds) ${ }^{13}$, and general technical assistance to milk industrialists (CORFO, 1962). These initiatives represented a deepening of the policies launched during the 1930s-1950s (Millar \& Fernández Abara, 2008) by governments convinced of the fact that milk consumption was good for the population's health. Indeed, all Chilean governments covered by our period of study have undertaken campaigns to show the population the benefits of consuming dairy products (Goldsmith, 2017; Ríos \& Coq, 2012) ${ }^{14}$.

As early as 1965, when an appraisal of Alessandri's governmental agricultural policies was completed, it accounted for an increase of $25 \%$ in the capacity of industrial milking plants (CORFO, 1965). The second half of the 1960s was also prosperous, and by the early 1970s there were already fourteen modern milk plants in operation (Ortega, 2017). For these plants to operate successfully, as well as to facilitate the activities of local milk producers, electrification of rural areas was needed. From the 1960s CORFO, through ENDESA (the national electricity company created in 1943) started to introduce electrification into rural areas of the country to support not only milk production but also poultry and pork facilities (Ortega, 2017). Industrial modes of production were increasingly responsible for the nation's milk. At the beginning of our period of study about half of all fresh milk was produced by industrial dairy establishments; by the early 1990s this figure had increased to three-quarters, and today it is over $80 \%$.

Other important processes and/or technologies were introduced into the production process, some imported from abroad. Particularly relevant was milk pasteurization, introduced comparatively late in industrial plants in Chile, although the global establishment of pasteurization was a slow process: it took over half a century to become common

13. In 1967 CORFO created the National Seed Company (Empresa Nacional de Semillas), a public company, in charge of providing high quality seed for milk producers (CORFO, 1978).

14. For similar campaigns elsewhere (e.g. Spain), see Pujol, Nicolau and Hernández Adell (2010). 
practice among producers (Valenze, 2011) ${ }^{15}$. In Chile in 1930 a pasteurization law was issued -although it was enforced only from 1935- that mandated pasteurization of the milk consumed within urban areas (Mardones \& Cox, 1942). In 1938 the National Feeding Council strongly supported milk pasteurization, not only on health grounds, but also to promote its national distribution (Yáñez Andrade, 2019).

This is an important distinction: during the early decades of our study the government's policies to promote milk consumption in Chile were mainly concerned with sanitary conditions in both production and consumption, rather than production alone (Moreno, 2017; Goldsmith, 2017). Authorities understood that the consumption of milk in Chile presented a health hazard at that time (Goldsmith, 2017). This concern was not unique to Chile: as late as the 1930s the populations of Europe and North America were not guaranteed safe milk at the market (Valenze, 2011). From the 1940s onwards pasteurisation was the norm in industrial plants in Chile, thus promoting milk production and consumption.

Another important development was the beginning of production and/or imports of powdered milk. Powdered milk had long been popular among lower socioeconomic groups, in particular in formulas for babies and children. It was seen as safe since it did not carry the bacteria present in fresh milk, and was thus unlikely to cause potentially fatal diarrhea (Bryder, 2009). It was also useful at times when there was a shortage of refrigeration facilities in the production chain and within households in many countries, such as Chile. Powdered milk was also portable and widely traded internationally and domestically ${ }^{16}$.

Nestle in particular played a crucial role in satisfying the state's demand for powdered and condensed milk. By the end of the 1940s most of the milk distributed by the State was still imported (Goldsmith, 2017). During the second half of the twentieth century Chile started to import increasing quantities of powdered milk, together with evaporated

15. Pasteurization of milk on a commercial scale started during the $1880 \mathrm{~s}$ in northern Europe, and from there it spread to the USA and other regions of the world. The initial recommendation was to heat milk for 30 minutes at around $60^{\circ} \mathrm{C}$. The temperature was later raised and the heating time reduced (High-Temperature-Short Time, HTST). Finally, Ultra High Temperature (UHT) pasteurisation processes were introduced, which took between 1 second at $88.3^{\circ} \mathrm{C}$ and 0.01 seconds at $100^{\circ} \mathrm{C}$ (HOLSINGER, RAJKOWSKI \& STABEL, 1997).

16. In the mid-1850s Gail Borden created a vacuum method to concentrate milk for storage, which was applied to the production of condensed milk (HAYASHI, 1989). Powdered milk, in turn, was first developed in England in 1855, although it was during the first decades of the twentieth century that it was widely traded internationally. Glaxo and Nestlé became the first companies to distribute it internationally (VALENZE, 2011; BRYDER, 2009), and Nestlé entered the Chilean market. 
milk and condensed milk, although to a lesser extent. The National Health Service was active in distributing powdered and condensed milk nationwide to the lower income strata of the population, children in particular, as well as to pregnant women.

Initiatives to distribute milk in Chile, in particular to the poor, had long been administered by the public sector and charitable organizations. The first of these was the Patronato de la Infancia, a charitable organization that aimed to provide care for mothers and children of lower socioeconomic groups, as well as medical care and education. Its best-known program was Gotas de Leche (milk drops) ${ }^{17}$, which provided special care and education to lactating mothers and children beginning in 1901, although its coverage was limited. In 1930 only 2,500 children received milk through the Gotas de Leche (Goldsmith, 2017). In 1954 the Government created the Programa Nacional de Alimentación Complementaria (PNAC, National Program of Complementary Feeding) to provide milk for pregnant women and children under six. By 1964 the National Health Service was distributing seven times more powdered milk than in 1953, and by the end of the 1970s fiftysix times more than at the end of the 1940s (Moreno, 2017). In 1970 the PNAC was attending 650,000 mothers and infants (Goldsmith, 2017), out of a total population of 1.15 million people. This role was later taken over by the Junta Nacional de Auxilio Escolar y Becas (JUNAEB), providing continuity in the distribution of breakfast and lunches at public schools until the present day (Moreno, 2017).

But this local demand for powdered and condensed milk was not only supplied with imports. In 1957 the first industrial powdered milk plant in Chile was built with UNICEF's support and supplied with fresh milk by local cooperatives (Moreno, 2017; Goldsmith, 2017). Many more plants were subsequently created. Previously, in the late 1930s future president Allende, while working as Minister of Salubrity, had created a joint enterprise with Nestle to produce condensed milk in Chile (Goldsmith, 2017). Thus, the country entered enthusiastically into the production of these two processed dairy products during the import-substitution period led by the state, which ended with the military coup of 1973 .

The 1970s-1980s were not good for milk production. Growth in overall production ceased, but not in per capita terms. The state's CORFO initiatives of the 1940s-1960s, including its companies, were either reverted or privatised after the military coup. There was a re-organization of the industry with more interference from the private sector and considerable volatility in production, impacted by the severe economic crisis of 1975-78 and more importantly that of 1981-83. The dairy sector had to adapt quickly to the new

17. As in Spain, the program was inspired by the previous French experience, aiming to improve children's nutrition but also to combat infant mortality (MUÑOZ PRADAS, 2012). 
environment, as well as to the fact that the National Health Service was increasingly buying heavily subsidised powdered milk from abroad rather than from local producers (Aravena, 2014).

In response, the sector made new investments to modernise production (this time funded with credit from private banks), further improved the genetic stock of dairy cows (greatly increasing milk production per animal) ${ }^{18}$, adopted new technologies such as tetra packs to commercialise liquid milk, introduced new products such as more yogurts and flavoured milks, and promoted mergers and acquisitions (Consorcio Lechero, 2018). By the late 1980s the sector was highly concentrated, with around five to six industrialists garnering close to $90 \%$ of the market, and a comparatively small number of fresh milk producers with large herds (Loncoleche, 1996; Aravena, 2014).

The current state of the dairy sector in Chile is healthy. Its industrial production is undertaken using the most up to date techniques. In 2019, the big seven companies were either multinationals or national companies. In the first group, the most important is the Swiss firm Nestlé, which has been operating in the country since 1934 and was the first to arrive in Chile. It is followed by the New Zealand Fonterra through Soprole and Prolesur, two formerly significant national companies acquired by this firm, and by the French Lactalis ${ }^{19}$. The most important Chilean company is Colún, a cooperative leader of the market. It is followed by Watt's (which acquired Loncoleche and Calo, two formerly influential national companies), Surlat and Quillayes ${ }^{20}$.

Equally importantly, there have been remarkable changes in the eating habits of the population. The consumption of yogurt increased dramatically, more than doubling from the early 1990s to the 2010s, to the extent that Chile now enjoys the highest per capita yogurt consumption in Latin America ${ }^{21}$. Yogurt is now widely consumed at breakfast or as a snack. Flavoured milks also appeared in Chilean families' consumption, as well as refrigerated desserts heavily based on milk. Similar developments occurred in other markets, such as Spain, which experienced significant diversification in dairy consumption (Collantes, 2014, 2016).

18. At the present time, there are around 600,000 dairy cows in Chile.

19. In turn, these multinational companies not only produced dairy products in Chile, but also imported powdered milk and cheese from their headquarters.

20. Formerly, the Italian Parlamat also operated in Chile (after acquiring the national firm Soprocar), but later sold its plants to Lactalis (NESTLÉ, 2012; ArAVENA, 2014; WATT's, 2016).

21. https://www.fedeleche.cl/ww4/index.php/informacion-2/leche-salud/82-leche-y-salud/3546-chilenos-consumen-14-litros-de-yogur-al-ano-y-lideran-en-latinoamerica; https://edairynews.com/es/ chileexplosivo-aumento-del-consumo-de-yogurt-dispara-produccion-local-9363/ [Accesed: 25 ${ }^{\text {th }}$ march 2018]. 
Cheese consumption also increased, to the extent that Chile now enjoys the highest cheese intake per capita in Latin America (Richard, 2018). This is partly explained by the fact that most Chilean families do not have dinner, but what they call once (Giacoman, 2010), which consists of abundant bread and tea or coffee during the late afternoon. So important is this tradition that Chileans consume ninety kilograms of bread per annum (nearly a quarter of a kilogram per day), and are second only to Turks in the world ranking of top bread consumers ${ }^{22}$. This is important because formerly bread was consumed with margarine, fruit jam, or avocado, but today it is consumed -at breakfast or tea timeincreasingly with cheese and/or ham. The most popular Chilean sandwiches are aliado (a combination of cheese and ham) and Barros Luco (hot meat and cheese). A recent study has shown that $81 \%$ of cheese consumers in Santiago eat most of the cheese they consume annually in sandwiches (Vargas-Bello-Pérez et al., 2014).

So important has been the growing consumption of cheese in the country that an increasing proportion of the milk received by industrial plants is now destined to be turned into cheese, rather than powdered milk. In the early 1990s the country produced around 35,000 tons of cheese; today it is producing over 100,000 tons of cheese per year ${ }^{23}$. The national yogurt production has also increased dramatically, from around twenty million liters in the early 1980s to 235 million liters in 2018 (ODEPA, 2019), showing the most dynamic growth of all products of the industry during the most recent decades.

\section{MEAT PRODUCTION, FOREIGN TRADE, AND CONSUMPTION}

Figure 6 shows the annual average consumption of meat in Chile (combining bovine, ovine, pork, equine and poultry products) in kilograms per person per year (yearly averages per decade). There was a remarkable degree of stability and stagnation during the 1930s-1980s, with an annual consumption at around 31-3 kilograms per capita per annum (except for the 1940s when it was slightly higher). This is a low figure, less than half that recorded in the colonial era in the country (Martínez Barraza, 2018). These were also times when beef was the most important meat in the Chilean diet, and the sector showed little improvement in efficiency of production, in particular during the 1930s-1960s. A report by ODEPA in the late 1960s accounted for the lack of improvements in produc-

22. https://www.24horas.cl/nacional/chile-se-consagra-como-el-segundo-pais-que-mas-consumepan-a-nivel-mundial-3492060 [Accesed: $2^{\text {th }}$ march 2018].

23. Although most cheese consumed in the country is home-made, imports of cheese have increased dramatically lately, from around 700 tons per annum during the 1980 s to around 24,000 tons annually during the last decade. 
tivity in cattle raising in Chile, in particular in areas such as cow feeding, sanitary conditions, and quality of cattle (ODEPA, 1968). This degeneration occurred despite the implementation of Alessandri's national livestock plan of 1961-70, which was more successful in the dairy sector. In addition, meats other than beef were not as widely consumed as they are today. National meat production was not sufficient to ensure the proper feeding of the population (Yáñez Andrade, 2019), since less than thirty-five kilograms per person per annum is well below the recommended intake of animal proteins.

\section{FIGURE 6}

Chilean per capita consumption of meat (ready-to-cook kilograms per year), annual averages per decade

100

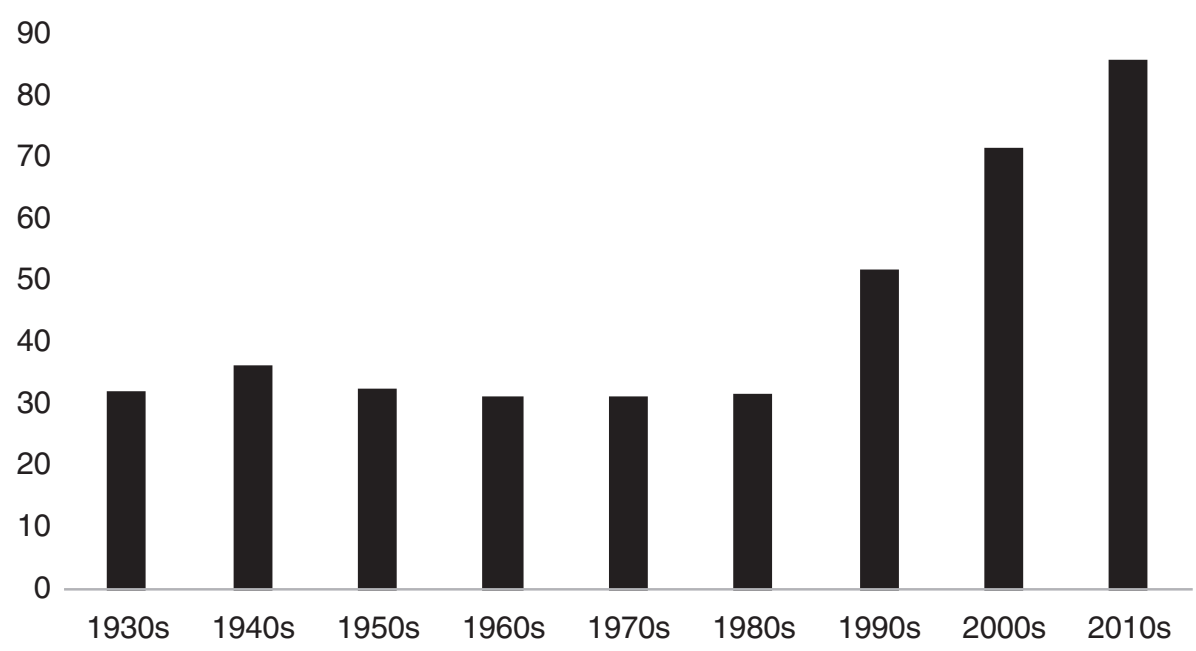

Sources: ODEPA (1970-1975); ODEPA (1976); ODEPA (1990-2017); ODEPA (2004-2017); Comisión Nacional del Medio Ambiente (2001); INE (2018); Banco Central de Chile (1977-2019); Oficina Central de Estadística de Chile (1930-1982); Cámara de Comercio de Santiago (1967-1982); CEPAL (1971-1989).

The 1970s and 1980s in particular experienced the lowest meat per capita consumption of the century, which is not surprising. The economic climate of the country was not favorable during those decades. GDP per capita behaved poorly during the 1970s and most of the 1980s (Figure 2). Furthermore, real wages plummeted (Figure 7), reaching -on average- the lowest levels since the 1930s (when Chile faced the impact of the Great Depression). This lowering of national and personal income did not help to increase the consumption of meat, a product characterized by having one of the highest income elasticity demands in the typical Chilean food basket. 


\section{FIGURE 7}

\section{Real average daily wages of workers in Chile, 1930s-2000s}

9

8

7

6

5

4

3

2

1

0

Source: Matus and Reyes (forthcoming).

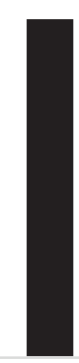

1950s 1960s

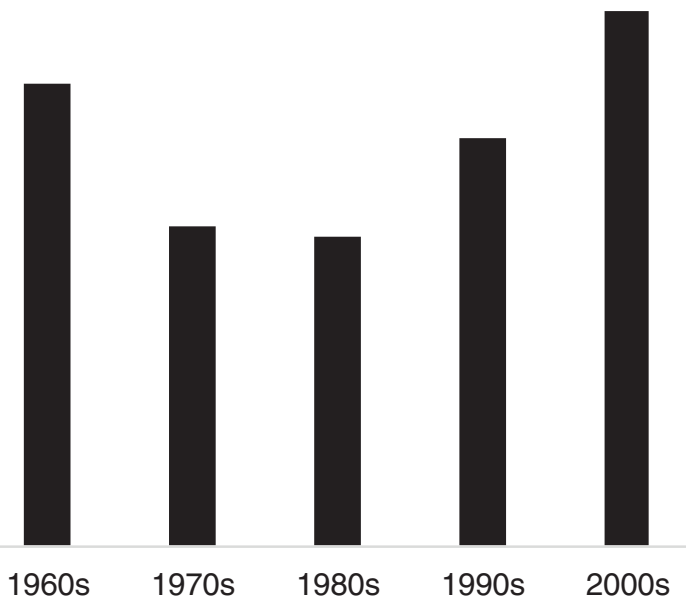

1970s 1980s 1990s 2000s

This low per capita meat consumption changed dramatically between the 1990 s and the 2010s, as did the consumption of dairy products, although the increase in meat eating was more significant. These were golden decades for the Chilean economy, when the country achieved its highest real wages ever (Figure 7) and the fastest growth of GDP per capita (Figure 2). As a result, Chileans are now consuming over 90 kilograms of meat per annum (more than 100 kilograms including fish and seafood) on average, an amount that falls within the levels recommended by FAO for developed countries (Nierenberg, 2005), and double the world average (Schnettler et al., 2014). According to the most recent data available from FAOSTAT, Chile's meat consumption for 2013 was only slightly less than that of Argentina and Brazil and greater than that of Uruguay. More importantly, the country's meat consumption is equivalent to that of Germany and above that of other developed nations such as the UK, Italy, Finland, and Sweden. In relative terms, the country's increasing consumption of meat is far more spectacular than the increasing per capita consumption of dairy products.

Partly as a result of this development, the country has shifted from the problem of having a dietary deficit to one of dietary excess (Albala et al., 2002) ${ }^{24}$, including obesity (part

24. Chile moved from having high rates of undernutrition to suffering increasing rates of obesity (Vio \& Albala, 2000). 
of a global trend affecting developing countries; Popkin, 2004), which is an issue for future agendas.

\section{FIGURE 8}

Real monthly per capita expenditure in meat (pesos of June 2017), according to the Surveys of Family Budget for Great Santiago, quantiles 1 (Q1) and 2 (Q2)

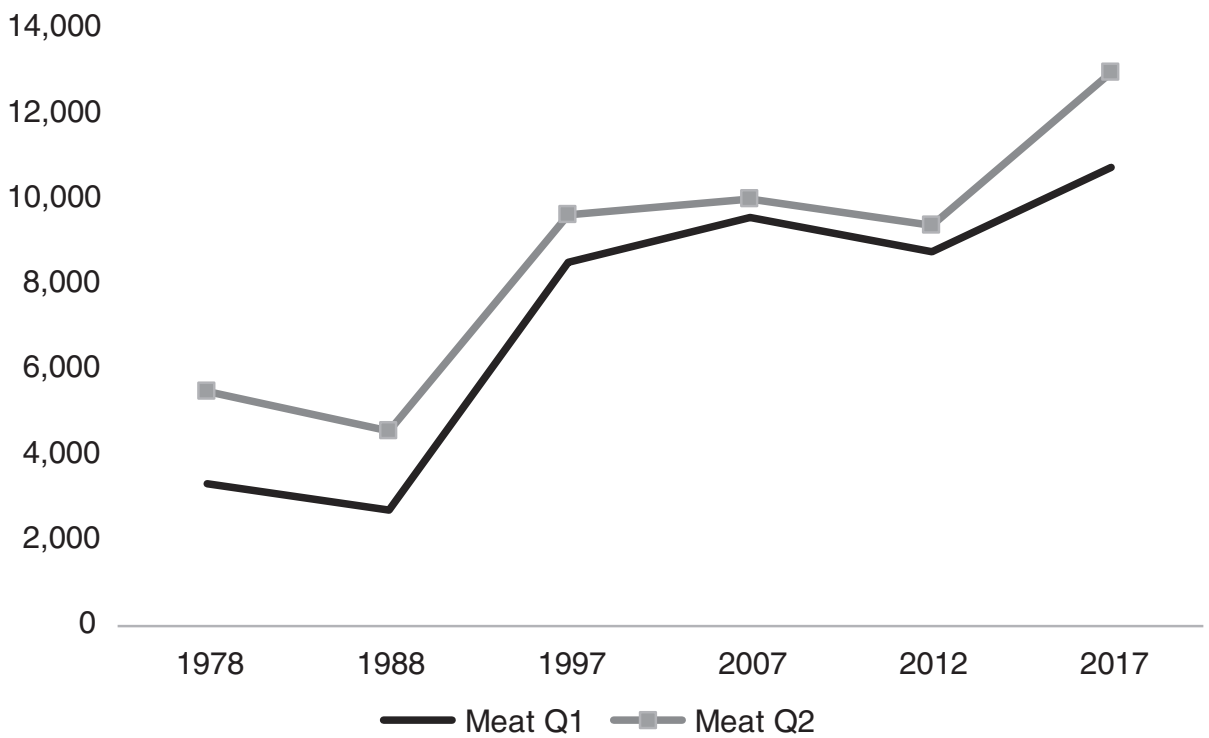

Source: own elaboration from National Institute of National Statistics, all Surveys of Family Budget from 1978, available at https://www.ine.cl/estadisticas/ingresos-y-gastos/epf [Accesed: 25th march 2018].

In line with our analysis of dairy products, we have contrasted our data on per capita consumption of meat (in kilograms) with per capita consumption in real pesos. The results are shown in Figure 8 for the poorest $40 \%$ in Greater Santiago. The real per capita expenditure in meat increased four-fold and three-fold between 1988 and 2017, for the first and second quantiles, respectively. This is a remarkable increase in only three decades, when prices were falling for most meat products.

This increase in meat consumption was mainly based on national production, rather than foreign supplies, although the country still imports meat. From 1990 onwards Chile signed numerous trade treaties with many key strategic partners, which substantially lowered import duties as well as paved the way to promoting exports of diverse products (Llorca-Jaña, 2015).Yet before 2000 the only meat imported in significant quantities was beef (in particular during the 1960s, 1970s and 1990s). Chile had a long tradition of live cattle imports beginning in the colonial era (in particular from Argentina; Gallardo, 2017) and subsequently imported chilled or frozen beef, but since the 1990s these imports have 
grown, amounting to over 150,000 tons per annum during the 2010s. However, this amount remains below the national production of beef (currently at over 200,000 tons per annum).

\section{FIGURE 9}

\section{Chilean per capita consumption of meat (kilograms per year)}

50

45

40

35

30

25

20

15

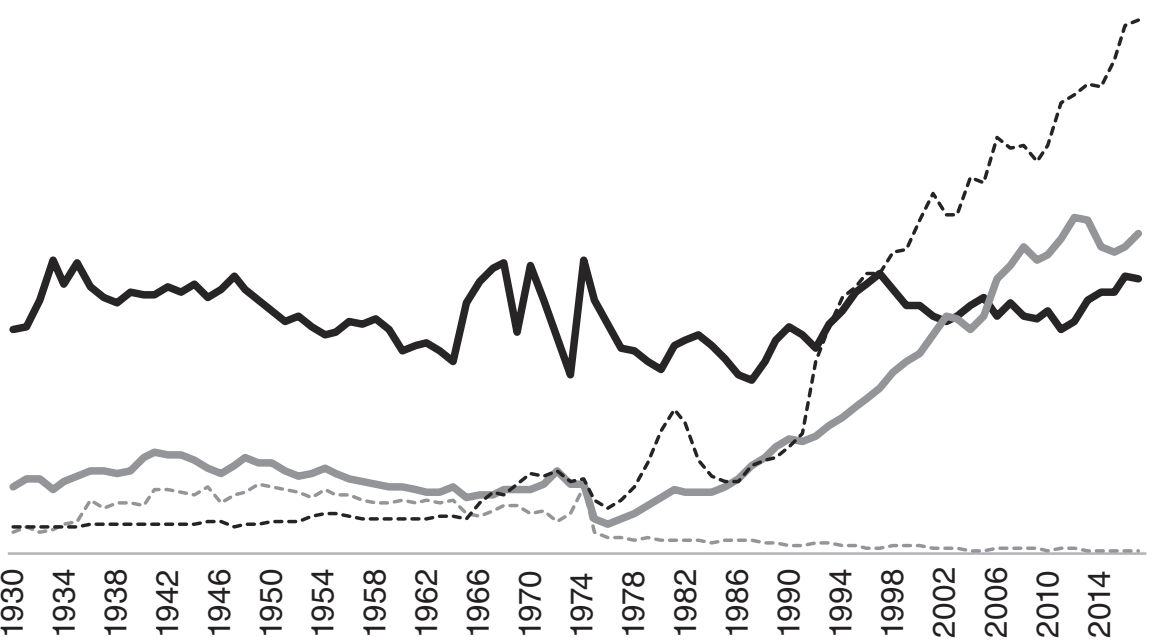

Bovine p/c

Ovine $\mathrm{p} / \mathrm{c}$

Pork p/c

Poultry p/c

Sources: ODEPA (1970-1975); ODEPA (1976); ODEPA (1990-2017); ODEPA (2004-2017); Comisión Nacional del Medio Ambiente (2001); INE (2018); Banco Central de Chile (1977-2019); Oficina Central de Estadística de Chile (1930-1982); Cámara de Comercio de Santiago (1967-1982); CEPAL (1971-1989).

During the most recent two decades imports of poultry -and of pork during the 2010shave been considerable. Yet Chileans prefer homegrown chicken, which is unfrozen, over imported chicken, which is bought frozen (Giacomozzi, 2015). Furthermore, during these decades Chile exported more pork and chicken than it imported (an example of international intra-industry trade $)^{25}$, so that on balance Chile is a net exporter, in particular of hog meat. The scale of the exports of pork have largely counterbalanced the imports of other meats, and of beef in particular, lessening the impact of the external sector on

25. The only important meat export in Chilean history before pork exports developed during the last few years was that of ovine meat, which was produced in the extreme south of the country, in the Magallanes region. Frozen lamb was extensively exported by the country, as well as consumed internally (MARDONES \& Cox, 1942). Magallanes was a pioneering centre for meat refrigeration in the country: from 1905 bovine refrigeration facilities were widely introduced (GALLARDO, 2017). 
national consumption ${ }^{26}$. Chile is now exporting nearly half of its pork products (Asprocer, 2018).

Disaggregating consumption per meat (Figure 9), it is clear that the dramatic increase in meat consumption is due to the spectacular rise of poultry (mainly chicken, with turkey in a distant second place) ${ }^{27}$ and pork within the Chilean diet: unsurprisingly millennials are also known as the chicken generation in Chile. As a result, as in Spain and Brazil, there has been a dramatic substitution of "red" meats in favor of "white" meats (Clar, 2008). Cheap chicken and pork meat led to this revolution on account of their lower prices combined with high income elasticity of demand, as has happened in many developing countries (Aho, 2002). Per capita GDP in Chile increased nearly three-fold between 1983 and 2010, while real wages nearly doubled between the 1980s and the 2010s.

Per capita consumption of chicken increased more than 20-fold between the 1930s and the 2010 s, while that of pork increased some $400 \%$ in the same period ${ }^{28}$. Beef consumption has remained stable during the whole period under study, resembling the Spanish case (Clar, 2008), while ovine meat has become less popular among Chilean consumers and is now largely exported. 1989 was the last year lamb featured in the Consumer Price Index Basket (CPIB). Today, as has been true from the colonial era onwards, Chileans consume some horsemeat, but less than a kilogram per person annually, and horsemeat never features in the CPIB.

The per capita consumption of meat in Chile is higher than per capita production, but only slightly. Although there are substantial beef imports (which come from a wide range of countries, from nearby Brazil, Argentina, and Paraguay, to distant USA and Australia), there are also sizeable pork exports. National production is the driving force behind the dramatic increase in national consumption. Chile, belatedly by international standards, joined the agro-industrial chicken and pork revolution in the 1990s and has made accelerated progress in the Fordist agri-business production system (Page, 1997).

26. As in most countries, in Chile most chicken is eaten fresh rather than frozen, while the international trade is largely in frozen chicken. This explains Chile's low level of imported chicken. Most commercial poultry meat is produced and consumed in the same country (AHO, 2002), and Chile is no exception.

27. Around $96 \%$ of all poultry consumed from the 1990s onwards consisted of chicken broilers (GIACOMOZZI, 2015).

28. The spectacular increase in pork production and consumption is not unique to Chile. In the early 1960s Spain consumed less than a third of the quantity of pork consumed by the USA; by the early 2000s it was consuming twice as much in per capita terms (CLAR, 2010). 
FIGURE 10

\section{Chilean production of meats (ready-to-cook equivalent), thousand tons (annual averages per decade)}

45

\section{0}

35

30

25

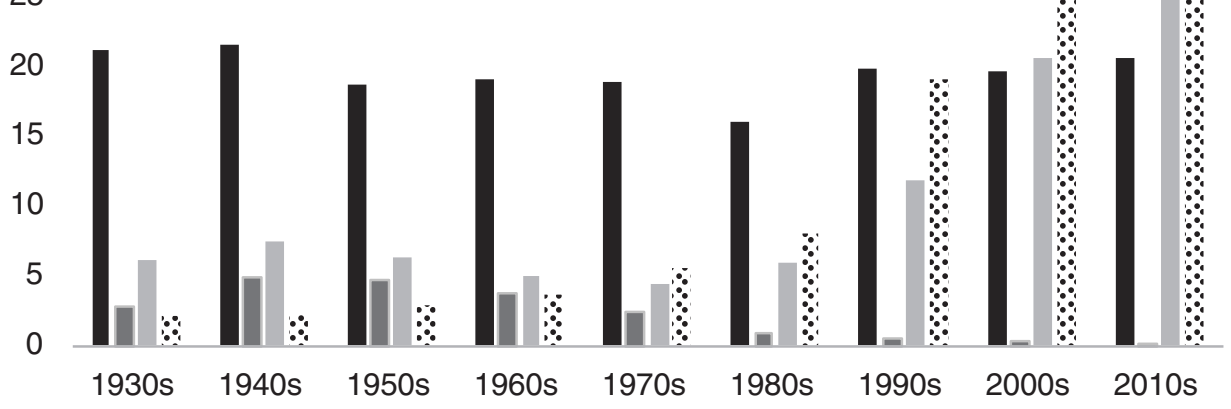

Bovine $\mathrm{p} / \mathrm{c}$

Ovine $\mathrm{p} / \mathrm{c}$

Pork p/c

$\because$ Poultry $\mathrm{p} / \mathrm{c}$

Sources: ODEPA (1970-1975); ODEPA (1976); ODEPA (1990-2017); ODEPA (2004-2017); Comisión Nacional del Medio Ambiente (2001); INE (2018); Banco Central de Chile (1977-2019); Oficina Central de Estadística de Chile (1930-1982); Cámara de Comercio de Santiago (1967-1982); CEPAL (1971-1989).

Up to the 1980 s the most significant meat produced in Chile was beef, accounting for between $57 \%$ and $64 \%$ of all meats produced in the country between the 1930 s and 1980 s, having benefited from the network of frigorificos (meat-packing houses) built during the CORFO era (Figure 9). The aggregated production of beef increased steadily from the 1930s until the late 1990s, although per capita heads of cattle have decreased continuously as the population has grown faster than the cattle (Figure 11). From the late 1990s, though, beef production has declined in Chile even in absolute terms: between 2007 and 2017 the total number of heads of cattle declined by nearly a quarter in the face of cheaper beef imports. Slaughter is concentrated in a small number of abattoirs: Frigorífico Osorno; Frigorífico Temuco; Firma SA; Frigorífico Simunovic; and Matadero Frigorífico del Sur Ltda. Beef production was the only sector in Chile that lagged behind technologically in the meat industry, in particular in comparison to chicken and pork production. The main change implemented by the beef industry was not technological but organizational: formerly most cows were sold in fairs or transported alive to distant markets (Gallardo, 2017); now they are taken directly to slaughtering plants controlled by these few companies, a process facilitated by transport improvements undertaken by the country (ODEPA, 2007). 
FIGURE 11

Per capita heads of bovine cattle in Chile, 1908-2010

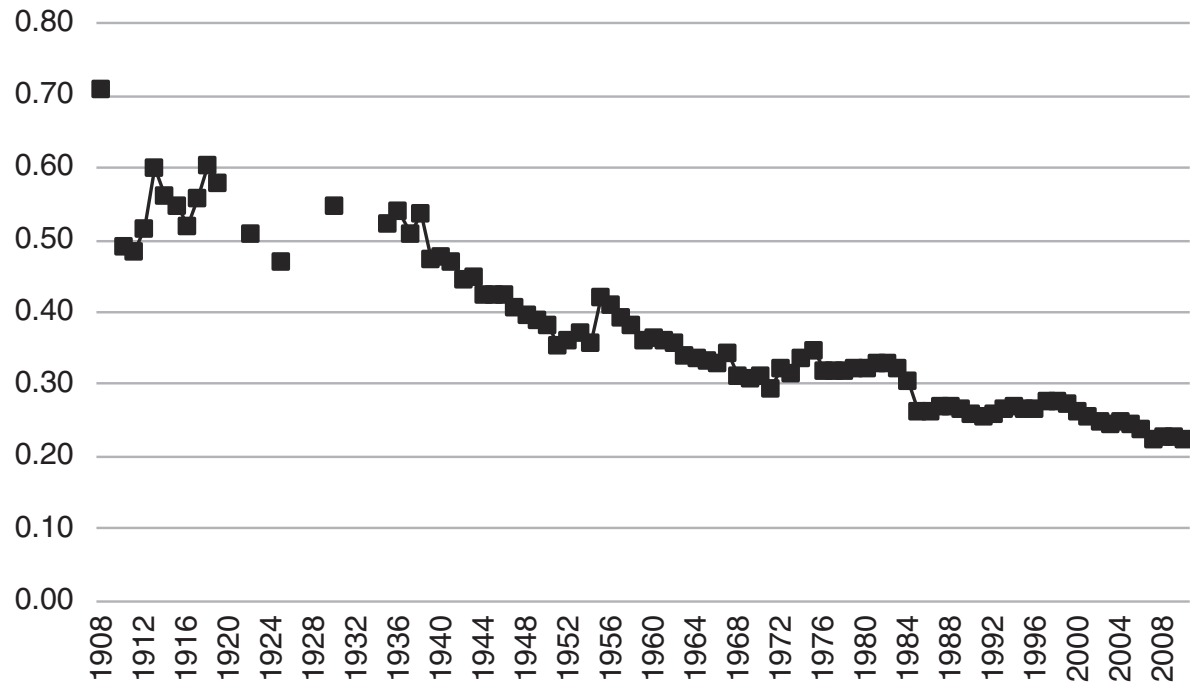

Sources: ODEPA (1970-1975); ODEPA (1976); ODEPA (1990-2017); ODEPA (2004-2017); Comisión Nacional del Medio Ambiente (2001); INE (2018); Banco Central de Chile (1977-2019); Oficina Central de Estadística de Chile (1930-1982); Cámara de Comercio de Santiago (1967-1982); CEPAL (1971-1989).

In contrast to beef, the most successful story of increasing meat production is that of poultry (chicken broilers in particular), which is part of a global phenomenon resulting from the emergence of organizational structures that helped to form what is believed to be the first modern agribusiness in the world (Godley \& Williams, 2007). This revolution was characterized by vertical integration as a means of reducing transaction costs ${ }^{29}$ and enjoying economies of scale. An increasing use of technology in many productive areas, including biological ones, led to systematic innovation, substantial increases in productivity and mass-production (Godley, 2014; Boyd, 2001; Boyd \& Watts, 2005; Aho, 2002; Martínez, 1999, 2002; Clar, 2008). Before, chicken meat was largely the incidental result of egg production (Boyd \& Watts, 2005; see also Martínez, 1999). Chicken first featured in the Chilean Consumer Price Index basket as late as 1969. During the most recent decades the growth of the poultry industry has been rapid in some developing countries, including Chile, as per capita income rose (Aho, 2002).

The modern industrial chicken industry, as we know it today, emerged in the US during the 1920s-1930s, but it was beginning in the 1950s that it gained further momentum

29. The stages included in vertical integration of the poultry industry are feeding mills, breeding facilities, laying flocks, hatcheries, growers and processing plants (CLAR, 2008). 
as a very efficient vehicle for transforming feed grains into higher-value meat production (Boyd, 2001; see also Rhodes, 1995). The US model was subsequently adopted by many other countries (Godley \& Williams, 2007). Amongst the most important innovations of the sector were successful confinement (essential for industrial production); adoption of formula feeding specially produced by a breeding industry (including the hybridization of corn and other crops); use of vitamin $\mathrm{D}$ (which made it possible to raise birds indoors ${ }^{30}$; use of antibiotics and vitamin B-12 to promote growth (also valuable for disease control); other successful disease control methods; the use of antioxidants; genetic improvements; electrification in industrial facilities; refrigeration throughout distribution channels; artificial incubators; adoption of factory processing at packing stations; self-service retailing; and development of poultry science (Boyd, 2001; Boyd \& Watts, 2005; Martínez, 1999, 2002; Nierenberg, 2005).

As a result of these transformations, the live weight of chickens increased dramatically, while the maturation period plummeted, bringing down feed conversion rates and retail prices of poultry, which now maintains a homogenous and consistent quality and is sold mainly in supermarkets. Global production of poultry has grown faster than that of any other meat since the 1960s thanks to the adoption of these cost-lowering production technologies and new organizational structures. Yet developing countries, such as Chile, were late adopters (Chang, 2007; Godley, 2014).

In Chile, during the 1960s-1970s the annual average production of chicken and turkey was only around 30,000 tons. The first serious attempts to promote industrial chicken production in Chile -of broilers in particular- date back to Eduardo Frei's presidency, when in the late 1960s a New Plan of Livestock and Poultry Development was launched aiming to substitute beef with poultry -and pork. The original plan was designed to reduce imports of beef (to save foreign currency, much needed in the country) and substitute the national production of chicken (Ortega, 2017). CORFO and Banco Estado extended loans and facilitated technical assistance for the installation of the first chicken plants for incubation, specialized poultry slaughterhouses, and specialized chicken feeding mills. A modern poultry slaughtering and packing house was inaugurated in 1966 in the capital of the country (Ortega, 2017).

The 1970s and 1980s brought further improvements and an increase in production, but it was during the 1990s and 2000s that national production intensified. It increased to over 200,000 tons and over 500,000 tons per annum, respectively, accounting for as

30. The vitamin was a comparatively new concept, first appearing in the scientific literature in 1912 (VALENZE, 2011). 
much as $45 \%$ of all meats produced in the country during the 2000 s, when prices were at their lowest. In the second half of the 1970s prices (per kilogram) of beef and chicken were at a similar level, but by the early 1990s chicken meat cost two-thirds less than beef. Thus, 1994 was a watershed in the history of Chilean meat consumption: for the first time Chileans consumed more chicken per capita than beef. The Chilean poultry sector was quickly transformed into a highly concentrated capital-intensive industry ${ }^{31}$, with a few large companies making low-cost products. Agrosuper (with its brands Super Pollo and Pollos King), Ariztía, Sopraval, Don Pollo and La Cartuja dominated the market, and many of these companies had acquired facilities from CORFO during the privatization process under Pinochet (CORFO, 1978).

For example, Sopraval, or Valparaíso's Poultry Producers Society, which was created in 1967, supported by CORFO, gathered together twenty-six producers of the region, each of whom owned their own raising facilities. The production process was quickly transformed. By 1985 the number of partners had been greatly reduced and the company had integrated vertically, controlling all stages of production (Sopraval, 1994; Valdivia, 2004). In 1996, Agrosuper acquired Sopraval, and now controls around half of the national production of chicken meat in Chile, followed by Ariztía (Agrosuper, 2012) ${ }^{32}$.

It is also significant that Chileans started to regard white meats as superior in quality to red meats. Chicken in particular was perceived as healthier than beef, given its lower fat and cholesterol content, combined with lower prices. An increase in income per capita allowed Chileans to eat chicken breasts and legs rather than chicken by-products (e.g. liver, spine $)^{33}$.

Like the poultry industry, the hog industry in some leading developed countries has experienced important technological and organizational changes since the 1950s, but at a slower rate than poultry production. The industry gradually changed from being dominated by outdoor production by family farms to indoor systems run by corporate enterprises enjoying technologically and vertically integrated production ${ }^{34}$, with productivity highest in the late 1970s (Rhodes, 1995). According to Martínez (1999), the changes in

31. This is similar to what happened to the industrial organization of the US poultry and hog industry; a handful of companies control the whole sector (NIERENBERG, 2005).

32. Currently the main poultry meat producers are in a federation called Asociación de Productores Avícolas de Chile (APA), created in 1991.

33. ODEPA (2007).

34. However, for some time factory farming of pigs operated together with traditional outdoor production, at least in Great Britain (Woods, 2012). 
structure in pork production reflected previous changes in the poultry industry (although they were only adopted in the 1960s, later than was originally assumed; Hurt, 1994).

The world pioneer in industrial pork production -or the factory-farm method- was once again the USA (Nierenberg, 2005; Clar, 2010). Beginning in the late 1970s, as soon as new technologies that allowed greater concentrations of animals were introduced drawing heavily on the principles of the poultry industry-, larger groups of hogs were concentrated at a single site in specialized capital-intensive buildings with mechanical systems of heating, cooling, feed delivery, waste removal, highly technological electric ventilation, and slatted floors, to which were applied boar semen techniques (artificial insemination), hormones, antibiotics (to promote growth and for disease control), other disease control procedures, genetic modification to obtain high quality lean meat, and fed with specially tailored manufactured feed. The required space per head dropped significantly in these new industrial pig farms within a short period of time.

As a consequence of these advances pork production costs decreased ${ }^{35}$ while the time needed to bring a pig from birth to slaughter decreased dramatically. These changes have led to a small number of large pig farms around the world, which substituted capital for labour (on a per hog basis). In these farms there was greater control over the quality and uniformity of pork meat, which is now sold after being packed in specialized and highly technological packing plants (either fresh or frozen), while processed pork products are also increasingly popular (Mayda, 2004; Page, 1997; Benjamin, 1996; Woods, 2012; Martínez, 1999, 2002; Rhodes, 1995; Hurt, 1994).

Chilean pork production increased remarkably thanks to these advances, from around 40,000 tons per annum during the 1940 s- 1970 s to 174,000 and 407,000 during the 1990 s and 2000s, respectively ${ }^{36}$. During the 1930s-1970s pork meat accounted for between $16 \%$ and $20 \%$ of all meat produced in the country; during the 2000 s this share increased to $34 \%$, second only to the poultry industry. Today the combined share of chicken and pork is over $80 \%$ of all meats, far more than the $25 \%$ they constituted during the distant 1930 s1940 s.

35. The quality of life enjoyed in particular by live hogs and broilers, but also confined animals in general, including fish, has deteriorated due to these new organizational and technological advances (see NIERENBERG, 2005). Countries such as Chile, where environmental laws are lax, generate many health problems for people living near chicken and pork industrial plants. This is the dark side of the history of meat production in Chile.

36. In the early 1940s the number of pigs in Chile was low. There were 10 heads of sheep for every pig, and little mutton or lamb was eaten (MARDONES \& Cox, 1942). 
The pork industry in particular witnessed far more rapid changes than the production of broilers, with production shifting from the 1990s to even larger highly technical farms, substantially lowering pork prices (Martínez, 1999, 2002; Hurt, 1994; Nierenberg, 2005). The Chilean pork industry adopted the most advanced available international technologies in pork production more quickly than the national poultry sector had done. The previous experience gained in the production of broilers helped in this development, as the case of Agrosuper illustrates through its Super Pollo and Super Cerdo brands. Super Pollo was created in 1974. Nine years later, its owner, Gonzalo Vial, decided to apply the business philosophy applied to chicken production to pigs, thus creating Super Cerdo, which soon became the leading company in the pork sector in Chile (controlling in total over two-thirds of national production). The company now has over 1,000 pork raising facilities (incorporating nearly 4 million pigs), several slaughtering factories and large pig food plants. The same organizational structure used by developed countries in pork processing was adopted in Chile, and as a consequence the local industry, like that of chicken processing, is highly concentrated within a few companies, all of which are vertically integrated: Agrosuper, Friosa, Coexa, Maxagro and Lo Valledor (Acuña \& Pizarro, 2019); a comparable situation exists in Spain and many other countries (Clar, 2010).

\section{OTHER DEVELOPMENTS IMPACTING ON THE CONSUMPTION OF MEAT AND DAIRY PRODUCTS}

Other changes taking place in Chile also affected the production, consumption and foreign trade of meat and dairy products. Supermarkets dominated sales of these products (especially dairy products initially) $^{37}$ thanks to modern refrigeration facilities, both for storing and retailing; other countries experienced similar retailing revolutions (Friedmann \& McMichael, 1989; Magnan, 2012; Collantes, 2016, 2018). The creation and expansion of the first hypermarket chains in the 1980s, which used their market power to exert downward pressure on prices, combined with decreasing production costs, greatly reduced consumer prices (Figure 11), and improved storage conditions for both dairy and industrial meat products ${ }^{38}$. Real prices of chicken in particular decreased dramatically from the mid1970s to the early 2000s: the average prices in the 2000s were half those of the 1970s. Average real prices of pork during the 2000 s were less than two-thirds (64\%) the prices of the 1970s, while beef prices remained stagnant.

37. A similar situation prevails in Spain, where dairy products were one of the key drivers in the Spanish retailing revolution (COLLANTES, 2016).

38. The first supermarkets were created in the US during the interwar period, expanding thereafter to developed countries, and from the 1980s-1990s to the rest of the world (CollanTES, 2016). 


\section{FIGURE 12}

Real wholesale prices of chicken and pork (pesos of March 2019) per kilogram, 1976-2017

2,500

2,000

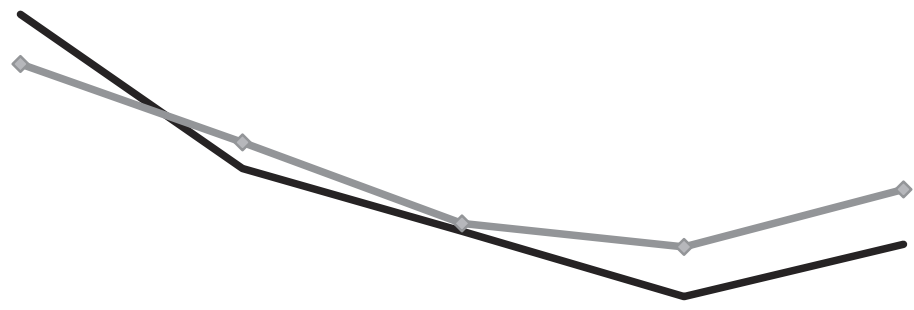

1,000

500

0

1970s 1980s 2000s 2010s

$\longrightarrow$ Chicken $\leadsto$ Pork

Note: prices are for January of each year, from 1976 to 2017.

Sources: ODEPA (2004-2017). Prices were deflated based on CPI from Díaz Bahamonde, Lüders and Wagner (2016). We then calculated decadal averages based on annual data.

The last three decades have witnessed an increasing concentration in the supermarket industry: Jumbo-Santa Isabel, Unimarc, Líder, Tottus, and Montserrat controlled the bulk of the sector. These giant supermarkets gradually replaced most specialty meat markets in the marketing of poultry and pork to consumers -although this was less true for beef-, a development which was part of the worldwide growth of the power of the supermarket (Magnan, 2012; Collantes, 2016). The quality control introduced by the industrial poultry and pork industries, as well as the standardization of production, has helped this process, as has happened in other countries (Friedmann \& McMichael, 1989). Internationally, customers value access to high-quality uniform products, which they can always find in a supermarket (Martínez, 1999). Most dairy products are sold in supermarkets in Chile, and at lower prices than elsewhere. Small shops in local neighborhoods also sell dairy products, but they are unable to match the low prices of supermarkets, so their market share is low.

At the beginning of our period of study the national refrigeration infrastructure of the country was underdeveloped, lacking large cold storage units and suitable means of dis- 
tribution, which posed problems for the distribution of meat and milk to customers as the products could only be distributed locally. In 1938 the National Feeding Council called for the establishment of a network of refrigerator warehouses as a means of improving the national distribution of both milk and meat (Yáñez Andrade, 2019; Mardones \& Cox, 1942). This development was reinforced in a new plan in 1947 (Millar \& Fernández Abara, 2008). A government report produced in the early 1940s provided a bleak picture: milk consumed in Santiago and Valparaíso arrived in ordinary trucks (unrefrigerated), necessarily from milk producers no more than $30 \mathrm{~km}$ away. This was the maximum distance unrefrigerated milk could be transported. In smaller cities and rural areas, milk was transported in carts, again without any refrigeration, exposing customers to food poisoning (Mardones \& Cox, 1942). The distribution of meat was equally problematic: most meat had to be sold in local slaughterhouses (usually under the administration of local councils; Gallardo, 2017) and fairs, which lacked refrigeration facilities and were restricted to small producers.

This situation slowly started to change with the adoption of the National Program of Economic Development of 1961, which instituted a national network of frigorificos, including refrigerated slaughterhouses (CORFO, 1962). In 1968 ENAFRI (the frigorificos national company) was created. By 1970 nine frigorificos had been started (CORFO, 1969, 1972). Although all were privatized during the 1970s, triggering a high level of concentration in slaughtering houses and meat packing and processing plants from the late 1970s, beef distribution continued lowering its costs. This highly concentrated industry remains in place today (ODEPA, 2007).

The considerable investment in improving refrigeration for producers and supermarkets was not enough to expand consumption. A final step was needed: as in other markets, a necessary condition to expand meat and dairy consumption was the installation of refrigerators within households. This was no easy task, in particular for a developing country. Even in developed economies, such as Britain, only $20 \%$ of households had a refrigerator by 1960 (Godley, 2014). The first household refrigerators arrived in Chile in the 1920s, but they were restricted to local elites on account of the high import price (Álvarez Caselli, 2011). It was not until the 1950s, when a national industry emerged (part of a strategy of state-led industrialization), that refrigerators started to feature in Chilean homes. But this was a slow process, as can be seen in Figure 11: by the late 1960s only $6 \%$ of Chilean households had a refrigerator. Refrigerators were first introduced into the Chilean Consumer Price Index basket as late as 1969 . Only by the late 1980s did this ratio increase to $50 \%$, and to over $80 \%$ by the end of the century. 
FIGURE 13

\section{Percentage of Chilean households with refrigerators}

90

80

70

60

50

40

30

20

10

0 70

\section{Percentage of Chilean households with refrigerators}

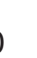

82 0 50 0 30 0

\begin{tabular}{l|l}
10 & 6 \\
0 & \\
\hline
\end{tabular}

1970

1982

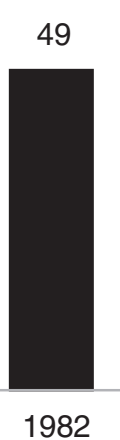

55

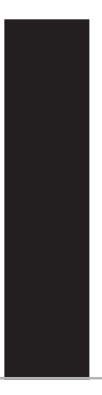

1992

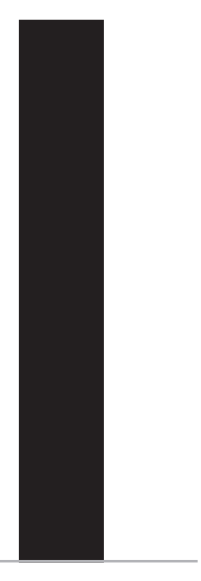

2002

Source: own elaboration from national censuses.

\section{CONCLUSIONS}

Between the 1930s and the early 1990s the diet of most Chileans was poor in animal proteins and calcium and relied heavily on wheat-based products and cheap carbohydrates. The consumption of meat was just slightly over thirty kilograms per person per annum, on average, which was well below the rate of national consumption during the last century of the colonial period (the eighteenth century) and well below the recommended intake of animal proteins by international health organizations. The consumption of milk improved during the period of state led industrialization (1930s-1960s) but remained low by international standards and in comparison with developed countries.

Today Chileans enjoy a diet characterized by a high consumption of meat and dairy products: the country experienced a profound nutrition transition within a short period of time, the 1990s-2000s, which was sustained thereafter. This process was delayed when compared to more developed countries, which experienced a similar transition around two decades earlier, in particular as far as poultry and dairy consumption was concerned, but Chile's experience was heavily influenced by international developments. The 1970s-1980s were particularly harsh for the Chilean economy, precluding any increase in the consumption of relatively expensive products such as milk and beef. 
The sudden rise in the consumption of meat and dairy products in Chile beginning in the 1990s was mainly associated with the country belatedly joining the international agribusiness revolution that impacted heavily on meat and milk production, triggering falling prices of food, and both sets of products had high income elasticity. The last three decades in particular have witnessed the widespread adoption of modern technologies applied to the production of broilers, hogs and dairy products, greatly reducing production costs and accelerating the production process due to this technological upgrading. Improvements in refrigeration facilities for production, storage, distribution, retailing and households have also further promoted the consumption of meat and dairy products.

Beginning in the 1990s there was an unprecedented growth in GDP per capita, a reduction in poverty rates, a mild improvement in income distribution, and a sustained increase in real wages, which also fostered the consumption of these products (as in Spain; Clar, 2008). There were also changes in the consumption habits of the population and government and private sector campaigns to promote the consumption of these products, especially dairy products (Ríos \& Coq, 2012). Other factors promoting this nutritional transition were the internationally acknowledged macro-economic stability enjoyed by the country since returning to democratic government (e.g. low inflation, business stability, lack of profound economic crisis) and the trade liberalization that began in the 1990s when the international political isolation of the country ended.

Finally, we must also credit the government support granted to the meat and dairy industries between the 1930s and the 1960s that made possible -in part- the growth from the 1990s, and several state policies promoting consumption. Of particular importance were the state's powdered milk distribution programs, which are still in operation; the granting of cheap credit to fund investment; the chartering of a pasteurization law; implementation of public-private initiatives; and the national electrification of the country. This revolution in consumption has greatly improved the nutrition of the Chilean population, partly explaining the improvement in its biological welfare. A warning note must also be sounded: the country now has high levels of obesity for the first time in its short history, partly due to the increase in meat consumption (Giacoman, 2010). Greater availability of cheap animal protein can no longer be necessarily linked to better health. Milk and meat production brings some environmental problems, which the country urgently needs to deal with: deforestation, water scarcity (since animals drink vast amounts of water), waste disposal, energy consumption, and global warming, all issues which stem from the so-called corporate food regime (Magnan, 2012). 


\section{ACKNOWLEDGES}

This article received funding from Fondecyt Regular 1180005 and Anillos ANID PIA SOC180001. We are very grateful to Instituto Nacional de Estadísticas (INE), Fedeleche, Claudio Vicuña Urqueta and to ODEPA's library, as well as to José Díaz Bahamonde, Anton Schuurman, Katharine Wilson, Sarah Hamilton, and to this journal's referees and editor.

\section{REFERENCES}

ACuÑa, D. \& PizArRo, M. J. (2019). La industria porcina en Chile: Oportunidades y desafíos para su sustentabilidad. Santiago: Odepa.

Agrosuper (2012). Memoria anual 2011. Santiago: Agrosuper.

Aguilera, M. \& ZúNIga, C. (2006). Políticas estatales de asistencia social en Chile: El problema de la leche, 1930-1970. Degree thesis. Santiago: Universidad de Chile.

Aно, P. W. (2002). The World's Commercial Chicken Meat and Egg Industries. In D. D. Bell \& W. D. Weaver (Eds.), Commercial Chicken Meat and Egg Production. New York: Springer Science.

Albala, C., Vio, F., Kain, J. \& Uauy, R. (2002). Nutrition Transition in Chile: Determinants and Consequences. Public Health Nutrition, 5 (1A), 123-28.

Almonacid, F. (2011). Transporte ferroviario y mercado agropecuario en Chile, 19301960. Historia Agraria, (53), 97-128.

Almonacid, F. (2016). Neoliberalismo y crisis económica: Políticas estatales, mercado y agricultores en Chile, 1973-1985. Historia Crítica, (62), 119-39.

Álvarez Caselli, P. (2011). Mecánica doméstica: Publicidad, modernización de la mujer y tecnologías del hogar 1945-1970. Santiago: Ediciones UC.

Aravena, L. (2014). Neoliberalismo y producción lechera en la provincia de Osorno: Transformaciones del rubro entre 1973 y 2007. Degree thesis. Valdivia: Universidad Austral de Chile.

Asprocer (2018). Reporte 2017. Santiago: Asociación Gremial de Productores de Cerdos de Chile.

Banco Central De Chile (1977-2019). Indicadores de comercio exterior. Santiago: Banco Central de Chile.

BAten, J. \& Blum, M. (2014). Why are you Tall while Others are Short?: Agricultural Production and other Proximate Determinants of Global Heights. European Review of Economic History, 18 (2), 144-65.

Benjamin, G. L. (1996). Industrialization in Hog Production: Implications for Midwest Agriculture. Chicago: Federal Reserve Bank of Chicago. 
BoyD, W. (2001). Making Meat: Science, Technology, and American Poultry Production. Technology and Culture, 42 (4), 631-64.

BoYD, W. \& WATTS, M. (2005). Agro-Industrial just-in-time: The Chicken Industry and Postwar American Capitalism. In D. Goodman \& M. WATts (Eds.), Globalising Food:Agrarian Questions and Global Restructuring (pp. 139-65). London: Routledge. BRYDER, L. (2009). From Breast to Bottle: A History of Modern Infant Feeding. Endeavour, 33 (2), 54-9.

CÁmara de Comercio de SANTiago (1967-1982). Comercio Exterior. Santiago: Cámara de Comercio de Santiago de Chile.

Chang, H. S. (2007). Overview of the World Broiler Industry: Implications for the Philippines. Asian fournal of Agriculture and Development, 4 (2), 1-16.

Clar, E. (2008). La soberanía del industrial: Industrias del complejo pienso-ganadero e implantación del modelo de consumo fordista en España, 1960-1975. Revista de Historia Industrial, (36), 133-65.

CLAR, E. (2010). A World of Entrepreneurs: The Establishment of International Agribusiness during the Spanish Pork and Poultry Boom, 1950-2000. Agricultural History, 84 (2), 176-94.

Collantes, F. (2014). La evolución del consumo de productos lácteos en España, 1952-2007. Revista de Historia Industrial, 23 (55), 103-134.

Collantes, F. (2016). Food Chains and the Retailing Revolution: Supermarkets, Dairy Processors and Consumers in Spain (1960 to the Present). Business History, 58 (7), 1055-76.

Collantes, F. (2019a). From Organized to Disorganized Capitalism? Market versus Nonmarket Coordination in Spain's Dairy Chain. Fournal of Agrarian Change, 19 (2), 295-318.

Collantes, F. (2019b). Why did the Industrial Diet triumph?:The Massification of Dairy Consumption in Spain, 1965-90. Economic History Review, 72 (3), 953-78.

Comisión ECONÓmiCa para América LATINA y EL CARIBE (CEPAL) (1971-1989). Bases de datos y publicaciones estadísticas. Santiago: Comisión Económica para América Latina y el Caribe.

Comisión NACIONAL DEL MEDIO AMBIENTE (2001). Guía para el control y prevención de la contaminación industrial: Industria procesadora de la carne. Santiago: Comisión Nacional del Medio Ambiente.

Conde, W. L. \& Monteiro, C. A. (2014). Nutrition Transition and Double Burden of Undernutrition and Excess of Weight in Brazil. The American fournal of Clinical Nutrition, 100 (6), 1617S-22S.

Consorcio LeChero (2018). Sector lácteo de Chile: Indicadores 2017. Santiago: Corporación Consorcio Lechero. 
Corporación de Fomento a la Producción (CORFO) (1961). Memorial 1960. Santiago: Corporación de Fomento a la Producción.

Corporación de Fomento a la Producción (CORFO) (1962). Memorial 1961. Santiago: Corporación de Fomento a la Producción.

Corporación de Fomento a la Producción (CORFO) (1965). Memorial 1964. Santiago: Corporación de Fomento a la Producción.

Corporación de Fomento a la Producción (CORFO) (1969). Memorial 1968. Santiago: Corporación de Fomento a la Producción.

Corporación de Fomento a la Producción (CORFO) (1972). Memorial 1971. Santiago: Corporación de Fomento a la Producción.

Corporación de Fomento a la Producción (CORFO) (1978). Privatización de empresas y activos, 1973-1978. Santiago: Gerencia de Normalización de Empresas.

Díaz BAHAMONDE, J., LÜDERs, R. \& WAgner, G. (2016). Chile 1810-2010: La República en Cifras. Santiago: Ediciones UC.

Dragoni, C. \& Burnet, E. (1938). L'alimentation populaire au Chili: Première enquête générale de 1935. Revista Chilena de Higiene y Medicina Preventiva, 1 (10-12), 409611.

FedELECHE (2013). Los 15 años de Fedeleche: La historia del gremio lechero relatada por sus protagonistas. Santiago: Fedeleche.

Friedmann, H. \& McMichael, P. (1989). Agriculture and the State System: The Rise and Decline of National Agricultures, 1870 to the Present. Sociologia Ruralis, 29 (2), 93-117.

Gallardo, E. (2017). Modernización ganadera en el sur de Chile: Osorno y sus contactos chileno-alemanes en perspectiva transnacional, 1917-1939. $\mathrm{PhD}$ thesis. Berlin: Freien Universität Berlin.

Giacoman, C. (2010). La obesidad en Chile en los albores del siglo Xxi. In C. Sciolla (Ed.), Historia y cultura de la alimentación en Chile: Miradas y saberes sobre nuestra culinaria. Santiago: Catalonia.

Giacomozzi, J. (2015). Actualización del mercado avícola. Santiago: Odepa.

Godley, A. (2014). The Emergence of Agribusiness in Europe and the Development of the Western European Broiler Chicken Industry, 1945 to 1973. Agricultural History Review, 62 (2), 315-36.

Godley, A. \& Williams, B. (2007). The Chicken, the Factory Farm and the Supermarket: The Emergence of the Modern Poultry Industry in Britain. Economics $\mathcal{E}$ Management Discussion Papers, (EM-DP, 2007-50).

GoldSMITH, J. (2017). Milk makes State:The Extension and Implementation of Chile's State Milk Programs, 1901-1971. Historia, 50 (1), 79-104.

GRIGG, D. (1995). The Nutritional Transition in Western Europe. Fournal of Historical Geography, 21 (3), 247-61. 
Hayashi, H. (1989). Drying Technologies of Foods: Their History and Future. Drying Technology: An International fournal, 7 (2), 315-69.

Holsinger, V. H., Rajkowski, K. T. \& Stabel, J. R. (1997). Milk Pasteurisation and Safety: A Brief History and Update. Revue scientifique et technique, 16 (2), 441-51. HuRT, C. (1994). Industrialization in the Pork Industry. Choices, 4 (1), 9-13. Instituto Nacional de Estadísticas (INE) (2008). Agropecuarias: Informe Anual 2006-2007. Santiago: Instituto Nacional de Estadísticas.

LlorCa-JaÑa, M. (2015). Trade Policy and Major Trends in Chilean Exports under Democracy, 1990-2012. Revista de Gestión Pública, 4 (1), 107-41.

Llorca-JaÑa, M., Araya, R. \& Navarrete, J. (2018a). Antropometría histórica de Chile: Evolución de la estatura de la población en el largo plazo, siglos XVIII-XX. Estudios Atacameños, 60 (1), 161-91.

Llorca-Jaña, M., Navarrete, J., Droller, F. \& Araya, R. (2018b). Height in Eighteenth-Century Chilean Men: Evidence from Military Records, 1730s-1800s. Economics and Human Biology, 29 (1), 168-78.

Llorca-Jaña, M., Navarrete, J., Droller, F. \& Araya, R. (2019). The Physical Stature of Men in $19^{\text {th }}$ Century Chile: Another Case of Stagnation during an Export Boom. Revista de Historia Económica-fournal of Iberian and Latin American Economic History, 37 (2), 239-70.

LONCOLECHE (1996). Memoria anual 1995. Santiago: Loncoleche.

Magnan, A. (2012). Food Regimes. In J. M. Pilcher (Ed.), The Oxford Handbook of Food History (pp. 1-23). Oxford: Oxford University Press.

Mamalakis, M. (1976). The Growth and Structure of the Chilean Economy: From Independence to Allende. New Haven:Yale University Press.

Mardones, J. \& Cox, R. (1942). La alimentación: Estudios del Consejo Nacional de Alimentación. Santiago: Impr. Universitaria.

MARTínez BARRAZA, J. J. (2018). Consumo y comercio de carnes en el corregimiento de Santiago, 1773-1778. Historia, 51 (2), 455-83.

Martínez. S. W. (1999). Vertical Coordination in the Pork and Broiler Industries: Implications for Pork and Chicken Products. Washington, DC: United States Department of Agriculture, Economic Research Service. (Agricultural Economic Report, 777).

MartíneZ, S. W. (2002). Vertical Coordination of Marketing Systems: Lessons from the Poultry, Egg, and Pork Industries. Washington, DC: United States Department of Agriculture, Economic Research Service. (Agricultural Economic Report, 807).

Matus, M. \& Reyes, N. (forthcoming). Precios y salarios en Chile, 1886-2009. In M. LloRCA-JAÑa \& R. Miller (Eds.), Una nueva historia económica de Chile.

MAYDA, C. (2004). Pig Pens, Hog Houses, and Manure Pits: A Century of Change in Hog Production. Material Culture, 36 (1), 18-42. 
Millar, R. \& Fernández Abara, J. (2008). Políticas agrarias en Chile: 1932-1958. Boletín de la Academia Chilena de la Historia, (117), 407-64.

Ministerio de AgRicultura (1970). Plan de desarrollo agropecuario 1965-1980: Síntesis. Santiago: Ministerio de Agricultura.

Monteiro, C. A., Mondini, L., SouzA, A. L. De \& Popkin, B. M. (1995). The Nutrition Transition in Brazil. European fournal of Clinical Nutrition, 49 (2), 105-13.

Moreno, I. (2017). El rol del estado en la lucha contra la desnutrición en Chile. Master's thesis. Santiago: Universidad de Chile.

MuÑoz Pradas, F. (2012). Las Gotas de Leche y el descenso de la mortalidad infantil urbana en España (1900-1936). Revista de Demografía Histórica, 30 (2), 127-64.

Nestlé (2012). Huellas de leche: Nestlé y el sector lechero, creciendo con Chile. Santiago: Asuntos Corporativos y Sustentabilidad, Nestlé Chile.

Nierenderg, D. (2005). Happier Meals: Rethinking the Global Meat Industry. New York: Worldwatch Institute.

Oficina Central de Estadística de Chile (1930-1982). Anuario estadístico de la República de Chile: Comercio exterior. Santiago: Impr. Nacional.

Oficina de Estudios y Políticas Agrarias (ODEPA) (1968). Plan de Desarrollo Agropecuario, 1965-1980. Santiago: ODEPA.

Oficina de Estudiosy Políticas Agrarias (ODEPA) (1970-1975). Indicadores Agroeconómicos. Santiago: ODEPA.

Oficina de Estudios y Políticas Agrarias (ODEPA) (1976). Estadísticas Agropecuarias, 1965-1974. Santiago: ODEPA.

Oficina de Estudios y Políticas Agrarias (ODEPA) (1983-1990). Boletín agroestadístico de la leche. Años 1958-1974 y 1980-82. Santiago: Oficina de Planificación Agrícola.

Oficina de Estudios y Políticas Agrarias (ODEPA) (1990-2017). Bases de datos de Comercio Exterior. Santiago: ODEPA. https://www.odepa.gob.cl/estadisticas-del-sector/bases-de-datos-comercio-exterior

Oficina de Estudiosy Políticas Agrarias (ODEPA) (1991-2019). Boletín de la leche 1990. Santiago: Oficina de Planificación Agrícola.

Oficina de Estudios y Políticas Agrarias (ODEPA) (2004-2017). Bases de datos de Producción Pecuaria. Santiago: ODEPA. https://www.odepa.gob.cl/informe-detallado-por-especie-o-categoria-pecuario

Oficina de Estudiosy Políticas Agrarias (ODEPA) (2007). Caracterización de la demanda de carne bovina y evaluación de bienes sustitutos. Santiago: ODEPA.

Oficina de Estudios y Políticas AgRaRias (ODEPA) (2019). Situación del mercado del yogur en Chile. Santiago: ODEPA. 
ORTEGA, E. (2017). Agricultura: Reforma y desarrollo (1964-1970). In A. RoJAS \& P. MANRÍQUeZ (Eds.), Reforma agraria 50 años después: Origen y desarrollo del proceso. Talca: Universidad de Talca.

PAGE, B. (1997). Restructuring Pork Production, Remaking Rural Iowa. In D. GoodMAN \& M. WATTS (Eds.), Globalising Food: Agrarian Questions and Global Restructuring (pp. 135-57). New York: Routledge.

Popkin, B. M. (1993). Nutritional Patterns and Transitions. Population and Development Review, 19 (1), 138-57.

Popkin, B. M. (2004). The Nutrition Transition: An Overview of World Patterns of Change. Nutrition Reviews, 62 (7 Pt2), S140-43.

Pujol, J., Nicolau, R. \& Hernández Adell, I. (2007). El consumo de leche fresca en Cataluña entre mediados del siglo XIX y 1935: La difusión de un nuevo alimento. Historia Agraria, (42), 303-25.

RHodes, V. J. (1995). The Industrialization of Hog Production. Reviezw of Agricultural Economics, 17 (2), 107-18.

RichARD, N. (2018). Industria del queso y sus aspectos culturales en Chile. RIVAR, 5 (14), 128-45.

Ríos, S. M. \& CoQ, D. (2012). La cadena de valor láctea en Chile desde la intervención estratégica del Estado. Cuadernos de desarrollo rural, 9 (68), 125-50.

RodríGuez WeBer, J. E. (2017). Desarrollo y desigualdad en Chile (1850-2009): Historia de su economía política. Santiago: Centro de Investigaciones Diego Barros Arana. SANTA MARía, J.V. (1935). La alimentación de nuestro pueblo. Santiago: Impr. San Vicente. Schnettler, B., Sepúlveda, N., Sepúlveda, J., Orellana, L., Miranda, H., Lobos, G. \& Mora, M. (2014). Consumer Preferences towards Beef Cattle in Chile: Importance of Country of Origin, Cut, Packaging, Brand and Price. Revista de la Facultad de Ciencias Agrarias, 46 (1), 143-60.

SchuUrman, A. J. (2013). Agricultural Policy and the Dutch Agricultural Institutional Matrix during the Transition from Organized to Disorganized Capitalism. In P. Moser \& T. VArLey (Eds.), Integration through Subordination: The Politics of Agricultural Modernisation in Industrial Europe (pp. 65-85). Turnhout: Brepols.

Sopraval (1994). Memoria Anual 1993. Santiago: Sopraval.

STECKEL, R. H. (1995). Stature and the Standard of Living. Fournal of Economic Literature, 33 (4), 1903-40.

Subsecretaría de Pesca y Acuicultura (2017). Plan estratégico para aumentar el consumo de productos del mar en Chile. Santiago: Subsecretaría de Pesca y Acuicultura. VALDIvia, C. (2004). Sector avícola chileno: Destino exportador. Feller Rate Visión de riesgo, 1 (1), 1-5.

Valenze, D. (2011). Milk: A Local and Global History. New Haven:Yale University Press. 
Vargas-Bello-Pérez, E., Aguilar, C., Toro-Mujica, P., Vera, R. R., Cerda, M. \& BRIONES, I. (2014). Characterization of Cheese Consumers in Santiago Province, Chile. Ciencia e investigación agraria, 41 (3), 327-35.

Vio, F. \& Albala, C. (2000). Nutrition Policy in the Chilean Transition. Public Health Nutrition, 3 (1), 49-55.

WatT's (2016). Memoria Anual 2015. Santiago: Watt's Alimentos.

Woods, A. (2012). Rethinking the History of Modern Agriculture: British Pig Production, c. 1910-65. Twentieth Century British History, 23 (2), 165-91.

YÁÑEZ ANDRADE, J. C. (2019). Cuando los médicos hablaron de economía: Familia, salario y alimentación en Chile (1930-1950). América Latina en la Historia Económica, $26(2), 1-22$. 


\section{APPENDIX}

TABLE 1

Share of meat (beef, chicken, pork and lamb) and dairy products within the Chilean Consumer Price Index Basket (percentage)

\begin{tabular}{lccc}
\hline CPl's year & Meat (excluding fish and seafood) & Dairy products & Meat \& Dairy products \\
\hline 1928 & 11.9 & 4.7 & 16.6 \\
1957 & 10.6 & 4.3 & 14.9 \\
1969 & 9.2 & 3.5 & 12.7 \\
1978 & 8.4 & 3.5 & 11.9 \\
1989 & 6.7 & 3.0 & 9.7 \\
1998 & 4.8 & 1.9 & 6.7 \\
2008 & 3.9 & 1.9 & 5.8 \\
\hline
\end{tabular}

Source: National Institute for National Statistics. 
TABLE 2

Monthly average per capita expenditure on meat and dairy products, according to the Surveys of Family Budget (SFB), Great Santiago, per quintiles and total

\begin{tabular}{|c|c|c|c|c|c|c|c|c|c|c|c|c|}
\hline \multicolumn{13}{|c|}{ Nominal per capita expenditure per quintiles } \\
\hline \multirow[t]{2}{*}{ Quintile } & \multicolumn{2}{|c|}{$\begin{array}{c}1978 \\
\text { (\$ of June 1978) }\end{array}$} & \multicolumn{2}{|c|}{$\begin{array}{c}1988 \\
\text { (\$ of June 1988) }\end{array}$} & \multicolumn{2}{|c|}{$\begin{array}{c}1997 \\
\text { (\$ of January 1997) }\end{array}$} & \multicolumn{2}{|c|}{$\begin{array}{c}2007 \\
\text { (\$ of April 2007) }\end{array}$} & \multicolumn{2}{|c|}{$\begin{array}{c}2012 \\
\text { (\$ of June 2012) }\end{array}$} & \multicolumn{2}{|c|}{$\begin{array}{c}2017 \\
\text { (\$ of June 2017) }\end{array}$} \\
\hline & Meat & $\begin{array}{c}\text { Dairy } \\
\text { products }\end{array}$ & Meat & $\begin{array}{c}\text { Dairy } \\
\text { products }\end{array}$ & Meat & $\begin{array}{c}\text { Dairy } \\
\text { products }\end{array}$ & Meat & $\begin{array}{c}\text { Dairy } \\
\text { products }\end{array}$ & Meat & $\begin{array}{c}\text { Dairy } \\
\text { products }\end{array}$ & Meat & $\begin{array}{c}\text { Dairy } \\
\text { products }\end{array}$ \\
\hline Quintile 1 & 66 & 25 & 431 & 152 & 4,244 & 1,492 & 6,627 & 2,604 & 7,439 & 3,330 & 10,721 & 4,718 \\
\hline Quintile 2 & 110 & 34 & 723 & 265 & 4,811 & 1,800 & 6,901 & 2,992 & 7,963 & 3,175 & 12,994 & 5,265 \\
\hline Quintile 3 & 168 & 52 & 1,121 & 387 & 5,288 & 2,053 & 7,231 & 3,352 & 9,369 & 3,842 & 13,308 & 6,234 \\
\hline Quintile 4 & 227 & 81 & 1,474 & 590 & 6,036 & 2,608 & 7,946 & 3,894 & 9,666 & 4,527 & 13,679 & 7,197 \\
\hline Quintile 5 & 411 & 159 & 2,377 & 1,102 & 7,841 & 4,200 & 9,498 & 5,901 & 12,415 & 7,601 & 16,866 & 10,137 \\
\hline Total & 206 & 74 & 1,270 & 518 & 5,720 & 2,480 & 7,707 & 3,826 & 9,551 & 4,695 & 13,693 & 6,864 \\
\hline
\end{tabular}

Real per capita expenditure per quintiles. All figures in pesos of june 2017

\begin{tabular}{|c|c|c|c|c|c|c|c|c|c|c|c|c|}
\hline \multirow[t]{2}{*}{ Quintile } & \multicolumn{2}{|c|}{1978} & \multicolumn{2}{|c|}{1988} & \multicolumn{2}{|c|}{1997} & \multicolumn{2}{|c|}{2007} & \multicolumn{2}{|c|}{2012} & \multicolumn{2}{|c|}{2017} \\
\hline & Meat & $\begin{array}{c}\text { Dairy } \\
\text { products }\end{array}$ & Meat & $\begin{array}{c}\text { Dairy } \\
\text { products }\end{array}$ & Meat & $\begin{array}{c}\text { Dairy } \\
\text { products }\end{array}$ & Meat & $\begin{array}{c}\text { Dairy } \\
\text { products }\end{array}$ & Meat & $\begin{array}{c}\text { Dairy } \\
\text { products }\end{array}$ & Meat & $\begin{array}{c}\text { Dairy } \\
\text { products }\end{array}$ \\
\hline Quintile 1 & 3,331 & 1,247 & 2,719 & 959 & 8,500 & 2,988 & 9,575 & 3,763 & 8,763 & 3,923 & 10,721 & 4,718 \\
\hline Quintile 2 & 5,500 & 1,686 & 4,562 & 1,675 & 9,636 & 3,606 & 9,972 & 4,323 & 9,380 & 3,740 & 12,994 & 5,265 \\
\hline Quintile 3 & 8,430 & 2,626 & 7,075 & 2,445 & 10,591 & 4,112 & 10,449 & 4,844 & 11,037 & 4,526 & 13,308 & 6,234 \\
\hline Quintile 4 & 11,407 & 4,045 & 9,305 & 3,724 & 12,089 & 5,224 & 11,483 & 5,627 & 11,387 & 5,333 & 13,679 & 7,197 \\
\hline Quintile 5 & 20,611 & 7,975 & 15,005 & 6,955 & 15,705 & 8,412 & 13,725 & 8,527 & 14,625 & 8,954 & 16,866 & 10,137 \\
\hline Total & 10,333 & 3,690 & 8,014 & 3,269 & 11,456 & 4,968 & 11,136 & 5,528 & 11,251 & 5,531 & 13,693 & 6,864 \\
\hline
\end{tabular}

Source: National Institute of National Statistics; all SFB from 1978, available at https://www.ine.cl/estadisticas/ingresos-y-gastos/epf [Accesed: 27 ${ }^{\text {th }}$ March 2018]. 